\title{
Policy and market drivers for advancing clean energy
}

\author{
Chapter submission for edited book “Advances in Clean Energy Technologies” \\ Steven Dahlke ${ }^{1}$ John Sterling ${ }^{2}$ Colin Meehan ${ }^{2}$ \\ Working draft, last updated 10/8/2019
}

\begin{abstract}
This chapter reviews important policies and market trends shaping the global development of clean energy technologies. Stimulus policies in the form of feed-in tariffs, tax relief, and renewable portfolio standards along with substantial research \& development enabled clean energy projects to overcome early commercialization barriers. As a result, clean energy project costs are now competitive with or lower than conventional fossil fuels in most markets around the world. Policymakers and energy consumers are responding by increasing clean energy targets to high levels approaching $100 \%$ in a growing number of jurisdictions. Business models are adapting to this new environment and energy market structures are evolving to enable successful operations of high renewable energy systems. Markets structures, policies, and technologies that enhance system flexibility for efficient renewable energy integration represent the most promising future area of research in this field.
\end{abstract}

Keywords: energy policy, energy economics, clean energy, renewable energy, wind, solar.

\footnotetext{
${ }^{1}$ US Department of Energy Solar Energy Innovator Research Fellow

${ }^{2}$ First Solar
} 


\section{Introduction}

Clean energy technologies have advanced at a remarkable pace in recent decades. Despite significant progress, an acceleration is desired by many to address today's multi-dimensional global challenges including climate change mitigation, poverty reduction, ecological degradation, economic growth, and national security [1]. The policy environment and market design surrounding clean energy have been among the most important factors determining where early-stage clean energy technologies are deployed. Often, these environments vary considerably around the world and are evolving rapidly. Such heterogeneity provides researchers with natural experiments to analyze and learn lessons from. Policies designed to stimulate early-stage growth have led to clean energy technologies being cost-competitive with conventional energy technologies. This has emboldened some governments to pass ambitious laws to decarbonize their economy by fully relying on clean energy. Looking forward, clean energy policy goals will evolve from early-stage technology stimulus to large-scale clean energy integration.

It is important for clean energy researchers to maintain an understanding of the evolving global policy and market environment as they work to develop and advance these technologies. This chapter samples the academic literature covering the economics, policy, and engineering topics relevant to clean energy policy and markets. It also industry, government, and non-governmental organization perspectives by incorporating press articles as well as documents from non-academic entities in the field. In doing so, it identifies policy structures and market environments that have proven effective in advancing clean energy technologies. The chapter then discusses the forces shaping the future of clean energy policy and market development. This review makes clear the development of clean energy technologies is closely linked with its local policy and market environment. It also shows how research and development (R\&D) priorities impact the early trajectories of clean energy technologies. In this way, the chapter serves as a useful reference for researchers to get introduced to the broad literature on this broad set of topics.

Policy and markets incent technological development, and conversely, technology development shapes the evolution of markets and policies. For example, early clean energy policies like feed-in tariffs, rebate/incentive programs, and renewable energy standards stimulated the deployment of wind and solar technologies. Successful early deployment facilitated cost reductions and additional technological development. Following this, policymakers were emboldened to further increase clean energy targets, and are now working on market reforms to accommodate high levels of wind and solar into the electricity system. On the other hand, early stimulus policies have been less successful so far in driving technological development in the transportation or heating and cooling sectors, and more aggressive follow-up policies and market design have not yet followed [2].

This story is divided into three time segments covering the past, present and future. An outline of the chapter structure is displayed in Figure 1. Past clean energy technologies were supported by early policies and significant public investments into research that helped stimulate new investment and cost reductions through learning by doing and economies of scale. The success of these policies led to certain clean energy technologies, wind and solar in particular, being cost-competitive with commonly-used conventional energy sources. This is having profound implications on the market structures underlying today's energy markets. Low-cost clean energy is putting pressure on conventional electricity generation, forcing some power plants to retire early. The increasingly decentralized nature of energy supply is leading to the expansion of markets managed by centralized network operators to balance clean energy resources that are increasingly farther from energy consumption. This is replacing traditionally-vertically integrated energy balancing regions. Low-cost clean energy technologies are also increasing the bargaining power of energy consumers, who are organizing and stimulating new investment through contracts negotiated directly with clean energy suppliers. 


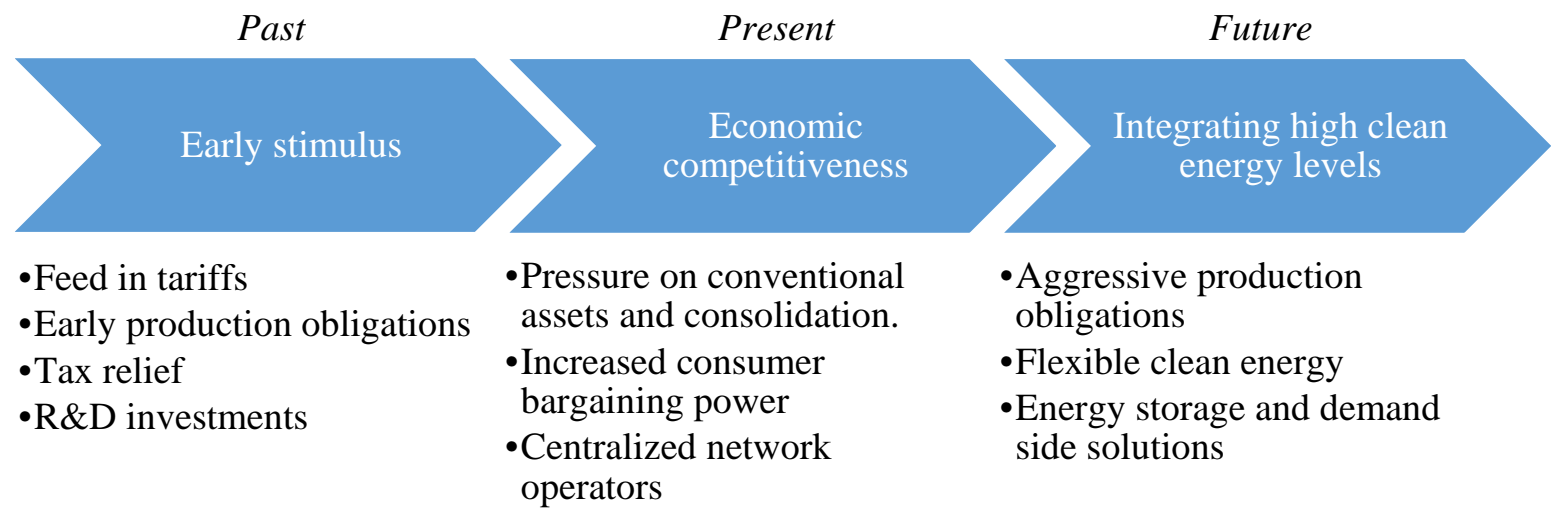

Figure 1 Evolution of clean energy policy and markets

Looking into the future, clean energy enabling strategies and resources will be important to manage the dynamic nature of a high clean energy system. Early levels of wind and solar variation are being costeffectively managed by centralizing and expanding electricity market territories. Relying on the flexibility in existing conventional and clean energy plants promises to be another source of low-cost flexibility for renewable energy integration. As clean energy continues to grow, storage along and improved technologies on the demand side will be needed. These areas present promising areas for technology researchers to help enable and accelerate the transition towards this future.

\section{Early stimulus policies}

\subsection{Global review}

Clean energy production has grown at an accelerating rate over the last two decades. Early policies in the form of feed-in-tariffs, tax credits, and renewable customer rebate programs were instrumental in supporting early growth. In parallel, manufacturing economies of scale and technological advancements dramatically reduced costs. Wind energy began significant growth in the mid-2000's, and has become a dominant source of clean energy source globally. In more recent years, solar has taken a significant share of global production, and is currently growing more rapidly than any other major source of clean energy, especially in Asia (see Figure 2).

Table 1 lists the top clean energy producing countries as of 2018. A historical policy review of these countries shows significant reliance on feed-in tariffs to stimulate early deployment of renewable energy, particularly in China [3]-[6], Europe [7]-[14], Japan [15], and India [16]-[19]. A feed-in tariff is a government-determined cost-of-service-based price for a producer typically paid by wholesale energy buyers. It is designed to provide long-term certainty to promote investment in clean energy projects. With recent cost-competitiveness of clean energy, policymakers are transitioning from administratively-set feed-in tariffs toward auction-based clean energy support schemes in order to incorporate competitive forces into the price-setting process.

Clean energy growth in the US was stimulated by targeted tax relief, including major federal tax incentives implemented in the early to mid-2000's [20], [21]. This includes a solar investment tax credit enacted in 2006 equal to 30\% of the project's invested basis, a level scheduled to gradually phase down through 2022 [22], [23]. Furthermore, the US wind industry has long benefited from a production tax credit equal to a dollar amount multiplied by the total amount of energy produced. The wind production tax credit (PTC) was first implemented in 1992, and has been adjusted, expired, and re-implemented 
many times throughout its ensuing history [24]. It has been gradually phasing down and will expire in 2020 [25].

\section{Total}
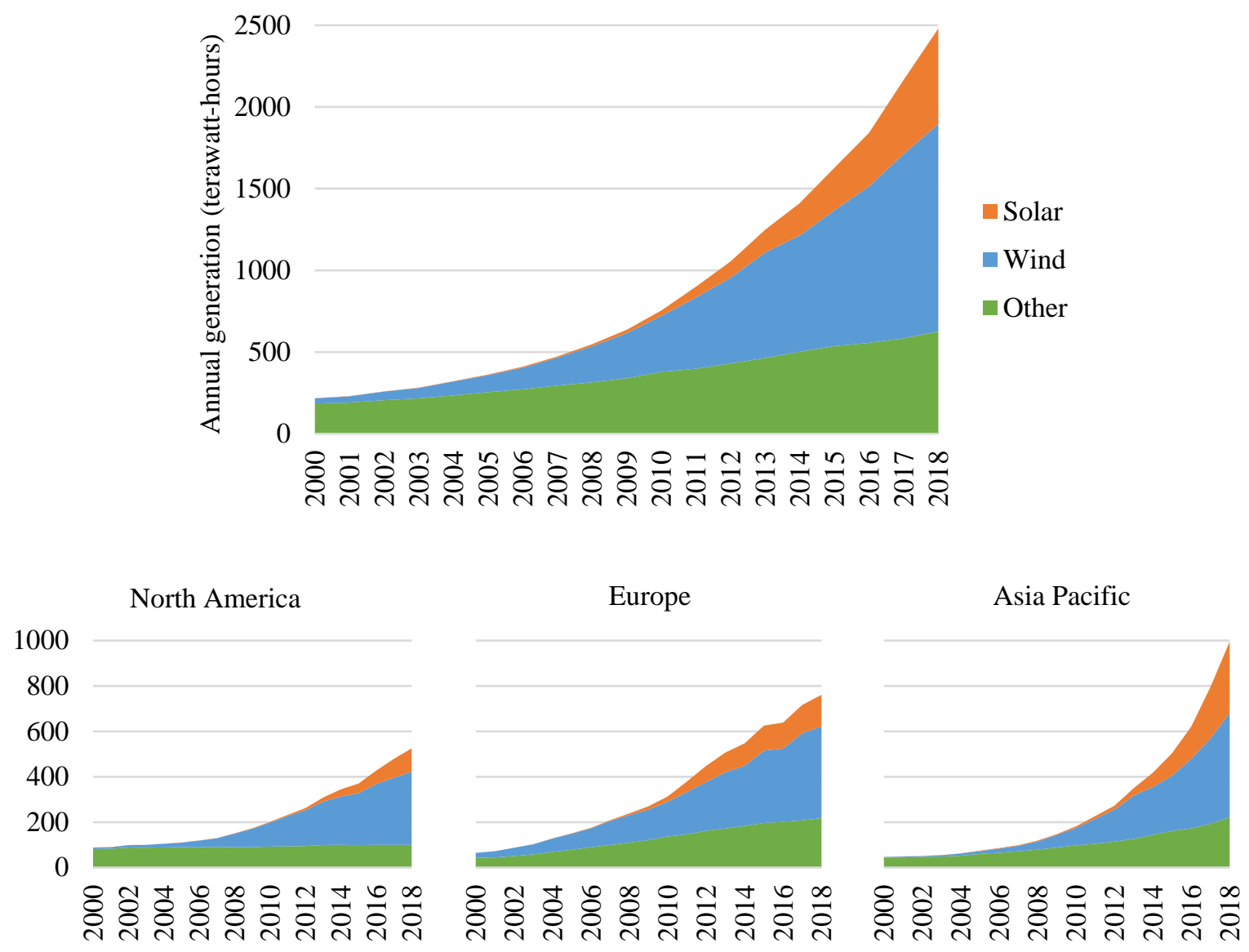

Figure 2 Global clean energy production by source and region. "Other" includes geothermal, biomass, and waste. Excludes hydroelectric energy [26].

Table 1 Clean energy production for top producing countries, 2018 terawatt-hours [26].

\begin{tabular}{rlcccc}
\hline Rank & Country & Total & Wind & Solar & Other \\
\hline 1 & China & 634 & 366 & 178 & 91 \\
2 & US & 459 & 278 & 97 & 84 \\
3 & Germany & 209 & 112 & 46 & 51 \\
4 & India & 122 & 60 & 31 & 30 \\
5 & Japan & 112 & 7 & 72 & 34 \\
6 & United Kingdom & 106 & 57 & 13 & 36 \\
7 & Brazil & 105 & 48 & 3 & 53 \\
8 & Spain & 71 & 51 & 13 & 7 \\
9 & Italy & 66 & 17 & 23 & 25 \\
10 & France & 47 & 28 & 10 & 9 \\
\hline
\end{tabular}


The impacts of consistent uncertainty around wind PTC extensions on development in the US demonstrated the policy's historical importance to the young industry. The tax credit was revised and extended twelve times between 1992 and 2012. Five of these extensions involved retroactively applying the tax credit to projects following lapse periods during which the subsidy expired [27]. Uncertainty derived from wind PTC expirations and extensions led to a "boom-bust" cycle of wind capacity growth in the US, shown in Figure 3. Early on, PTC lapses occurred before years where wind installations were almost entirely halted, during 2002, 2004, and 2006. The decrease in installations during 2010 and 2011 were largely attributed to a global economic recession. The low installations in 2013 was related to a late PTC extension during that year [28]. The created challenges for long-term contract negotiations and added costs from ramping up and down the industry's supply chains [29]. Despite these complications, the wind PTC was an important policy in aiding the overall successful growth of the US wind industry, currently the second-highest wind energy producing country in the world.

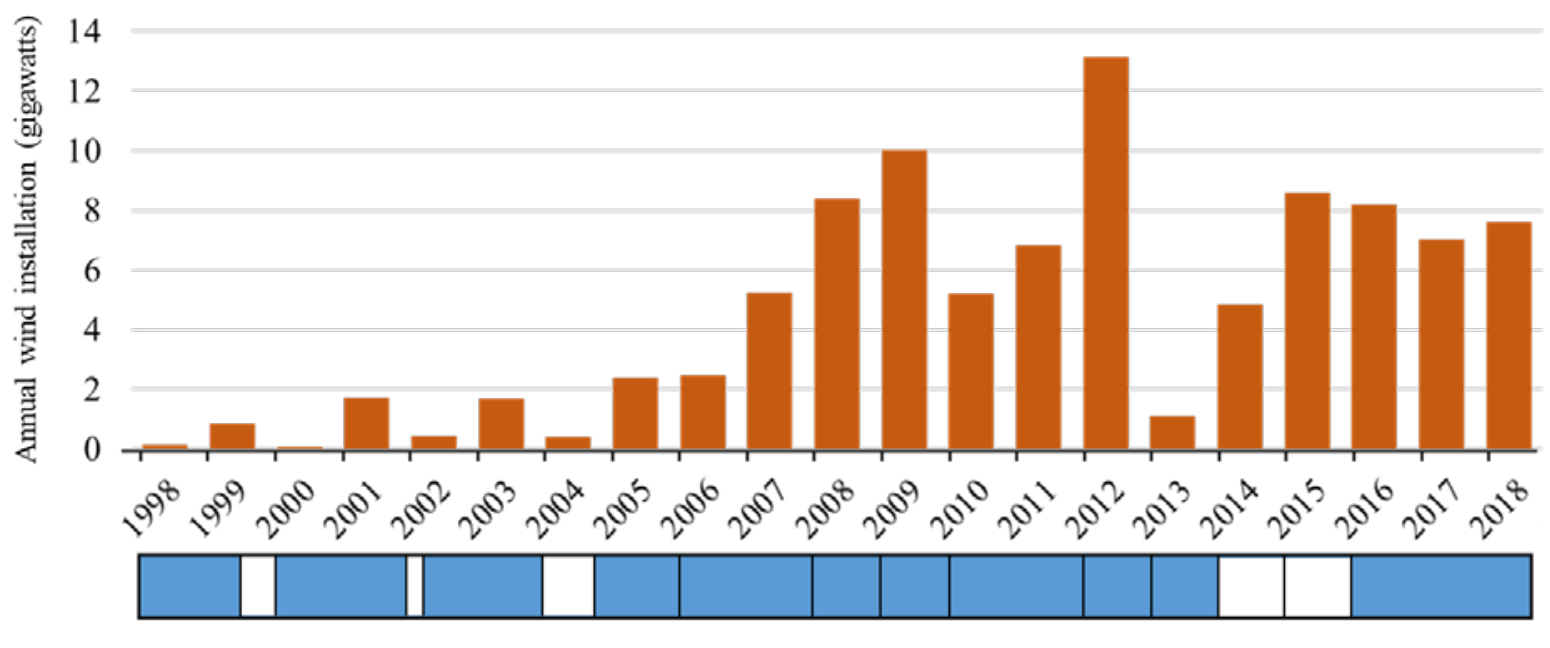

PTC extensions and lapses

Figure 3 Annual wind capacity installations and production tax credit timeline, United States [27], [30]. Black lines on the timeline indicate PTC expirations and extensions, white portions indicate periods of lapse.

Early stimulus policy in the United States (US) was in the form of a feed-in-tariff like policy under the Public Utility Regulatory Policies Act (PURPA) passed in 1978. A component of this legislation included a requirement for vertically integrated utilities to purchase renewable energy from independent producers (“Qualified Facilities” or QFs) at a pre-determined “avoided cost” rate, much like a feed-in-tariff. Unlike more successful feed-in-tariff policies, the PURPA QF model allowed utilities to determine their "avoided cost rate subject to approval by their in-state regulators. As a result, this policy was generally unsuccessful due to its fragmented nature and reliance on a favorable utility/regulatory structure to support investments in new projects. While some qualifying thermal generation was able to take advantage of this policy, wind and solar power in the 80's and 90's were still well above utility avoided cost. Today some wind and solar developers are leveraging this legacy policy under a more favorable combination of market conditions but its impact has been far more limited than other successful policies in the US.

More successful later stimulus policy in the US, after significant capital cost declines in wind and solar power was characterized by clean energy production requirements enforced by state governments, called renewable portfolio standards (RPS) [31]-[34]. These targets vary by state. For example, California has a binding requirement for the state's energy producers to generate $60 \%$ of electricity from renewables in 
2030, and make all electricity carbon free by 2045 [35], [36]. In contrast, 21 states in the US have no binding renewable portfolio standards [37].

Following the US's early success with RPS, China is in the process of implementing renewable electricity quotas to help mitigate high renewable energy curtailments [38]-[41]. The new quota system will include short-term requirements that vary by province depending on resource endowments [42]. China experienced remarkable growth in the last decade that propelled it to be the leading clean energy producing country in the world after surpassing the United States in 2017. The country's rapid buildout of renewable energy outpaced its transmission grid. In addition, China's early policies incentivized clean energy capacity buildout with less consideration to appropriate siting and market structures to maximize clean energy production [43]-[46]. As a result, high clean energy curtailment rates were an issue. The new quota system is designed to address these shortcomings and increase clean energy utilization.

Following the success of these leading countries, almost every nation on the planet now has a renewable energy target. These targets represent official goals specifying the government's preferred direction and production levels of clean energy. Roughly half, or 98 countries, have supplemented this position by passing at least one financial support policy in the form of a feed-in tariff, renewable energy production obligation, or tax relief [47]. 'Production obligation' is a general term that encompasses the US's renewable portfolio standards and China's renewable quotas, among other similar policies. Most countries lacking any financial support scheme are located in Central Asia and Africa (Figure 4).

A global review of clean energy feed-in tariffs and production obligations indicates governments more commonly rely on feed-in tariffs (Table 2). Perhaps surprisingly, more support policies target bioenergy than any other clean energy technology, despite bioenergy production being surpassed by wind and solar energy in the last decade. Technologies that convert biomass to usable energy forms have not maintained cost competitiveness with wind and solar technologies [48]-[55]. The role of biomass in the clean energy future remains uncertain, but its recent history demonstrates that clean energy growth requires successful research, development, and economies of scale in addition to policy support. In other words, stimulus policies alone will not result in widespread deployment if they do not lead to cost reductions that outcompete alternative technologies. Policies designed to support technology innovation are also an important part of the story [56]. In this spirit, the next section turns to the topic of research, development, and clean energy technology costs.

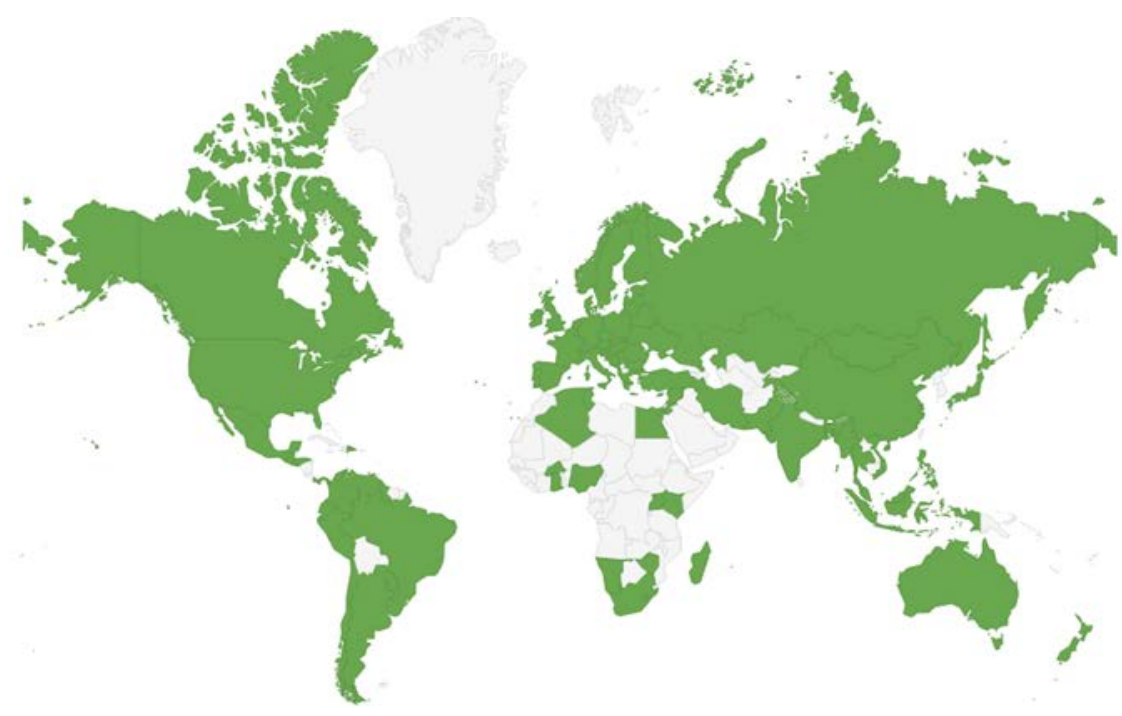

Figure 4 Countries with a clean energy financial support scheme or mandate [47]. 
Table 2 Total number of feed-in tariffs and clean energy obligations implemented by technology [47].

\begin{tabular}{lcccc}
\hline & Any & Wind & Solar PV & Bioenergy \\
\hline Feed-in tariffs & 224 & 110 & 88 & 113 \\
Production Obligations & 63 & 18 & 11 & 42 \\
\hline
\end{tabular}

\subsection{Research and development}

Clean energy technology today was built on substantial early and ongoing research and development (R\&D) efforts. Clean energy research ramped up in Europe and the US after the Arab Organization of Petroleum Exporting Countries (OPEC) embargoed oil exports to these regions [57]. Within Europe, Scandinavian countries and Germany were early leaders in establishing renewable energy research programs during this period [58].

The early response from the U.S. to the oil embargo involved the establishment of research programs to develop solar and wind energy technologies in addition to promoting other non-petroleum energy sources for national security. US federal R\&D funding for renewable energy increased from \$15 million nominal US dollars in 1975 to \$542 million in 1980, the latter being equivalent to \$1.7 billion 2019 dollars [59]. This involved establishing a Department of Energy in 1977, and in the same year founding the Solar Energy Research Institute, later renamed the National Renewable Energy Laboratory [60]-[63]. Around the same time, the US established a program to develop early-stage large horizontal-axis wind turbines in the National Aeronautics and Space Administration's (NASA) Glenn Research Center in Cleveland, Ohio [64], [65].

European renewable energy research expenditures also increased sharply in the late 1970's [66]. The International Energy Agency was established in 1974 to act as a counterweight to OPEC's global influence on the world energy stage [67]. Denmark established a successful early wind industry that gave a first-mover advantage to leading Danish wind companies, despite relatively smaller amounts invested in government R\&D [68]-[70]. Sweden invested public dollars that enabled a successful transition away from oil imports towards biomass-based sources of energy [71], [72]. Germany also aggressively ramped up its $R \& D$ programs during this time, increasing renewable energy research spending from the equivalent of \$10 million nominal US dollars in 1974 to \$150 million in 1982 [73].

Modern clean energy technologies were shaped by the significant advances made during the flurry of renewable energy research beginning in the 1970's, and public R\&D spending has continued to support technology advances into the present. Figure 5 breaks out current renewable energy R\&D spending by IEA member country. It shows the United States leading this club, followed by Germany and Japan. A longer-term time series of government renewable energy research spending shows a strong correlation with the oil price. In this way, oil price is likely a good predictor of future renewable energy research support. Figure 6 plots government renewable energy R\&D spending over time by IEA member countries, along with the global oil price. It shows a significant drop off in spending in the 1980's after the oil crisis subsided. This was followed by a period of relatively stable spending until another wave of clean energy research spending increase following the oil price surge beginning in the mid-2000's. R\&D spending has partially subsided again after a recent oil price drop.

Early stimulus policy and R\&D support were instrumental to the development and scaling of clean energy technologies. Substantial cost reductions occurred in parallel to clean energy growth, particularly for wind turbine and solar photovoltaic (PV) technologies. Wind energy's scale economies are largely a story of unit cost savings through increasing turbine size. Solar photovoltaic cost reductions were due to a variety 
of improvements in panel efficiency as well as manufacturing and supply chain optimization over time. These cases demonstrate technological success through incremental improvements rather than a single breakthrough [74].

Wind turbine technology converged in the mid-1980's to a dominant three-blade and horizontal axis design [75]. Since then, new turbine technology has largely been characterized by improved efficiencies through increased turbine hub height and larger rotor diameters, enabling plants to access higher sustained winds more efficiently [76]. Figure 7 displays growing tower heights and cost reductions since the early 1980's. Rapid unit cost reductions took place from the 1980's to early 2000's. Since then, the rate of unit cost reductions has slowed as the best sites have been developed, and demand for inputs became more competitive [77]. However, experts predict wind project costs will continue to decrease another 20-40\% over the next few decades due to larger rotor sizes, taller towers, advancements in controls, and improved material design [78].

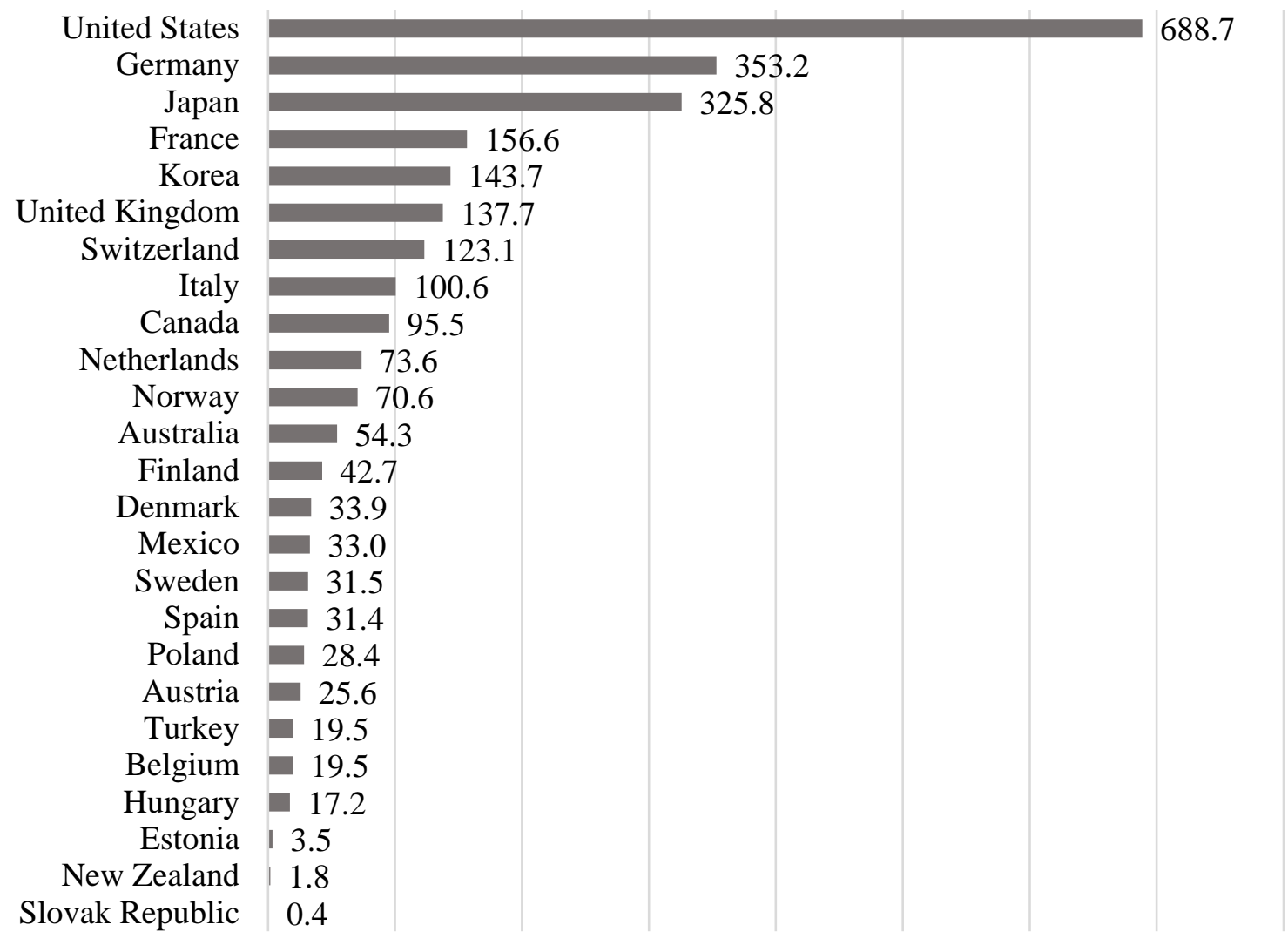

Figure 5 Renewable energy R\&D spending by IEA member country in 2017, million US dollars [79]. 


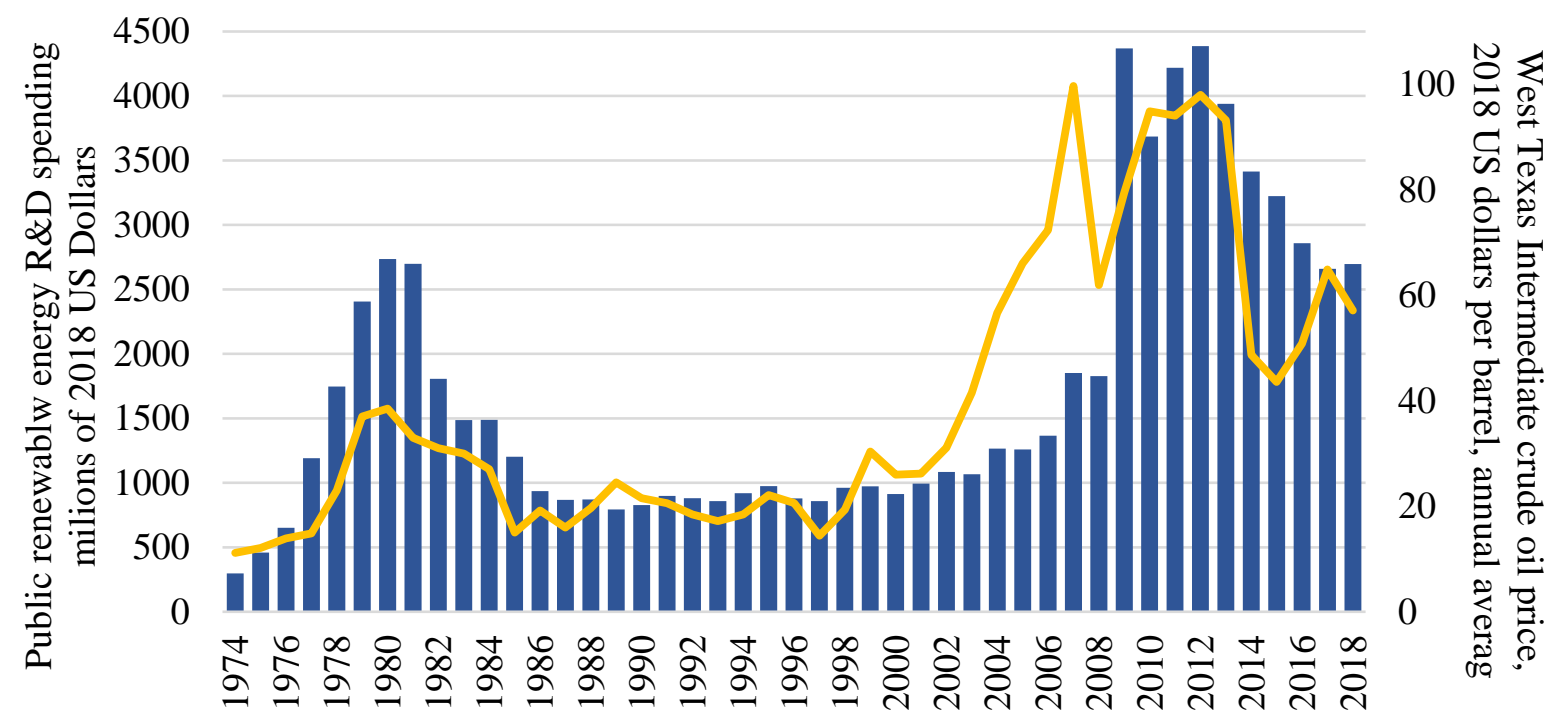

R\&D spending Oil price

Figure 6 IEA member country renewable energy R\&D spending and global oil price over time [79], [80].

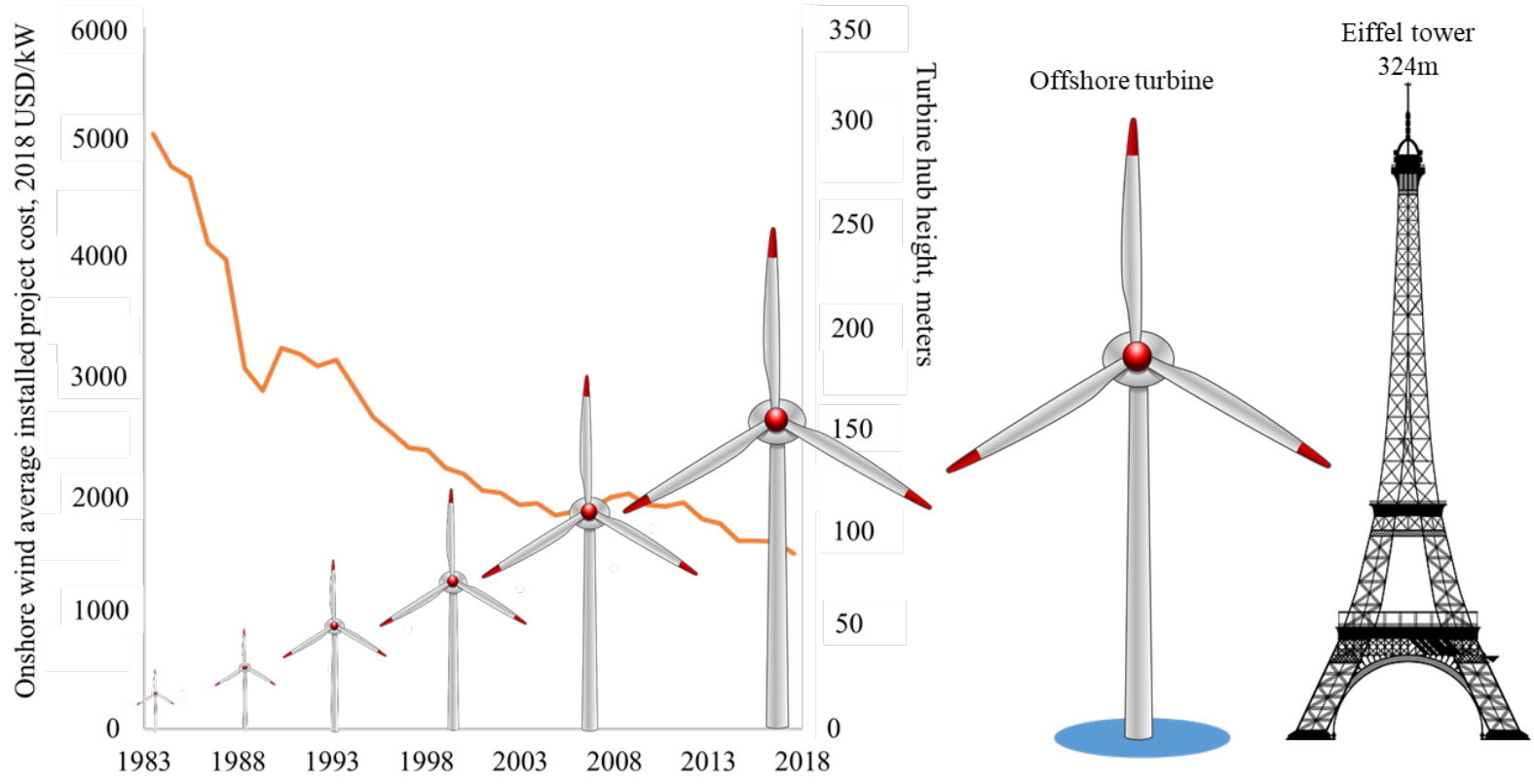

Figure 7 Wind turbine growth and cost declines over time [81]-[86]

Solar energy technology development in the mid-20 $20^{\text {th }}$ century was largely motivated by applications for space exploration and subsequently remote terrestrial applications including oil, telecommunications, and maritime [87]. In the early 2000's, Germany followed by other countries passed feed-in tariffs that jumpstarted the growth of commercial solar PV for grid electricity production [13]. Solar technology advancement during this first decade of the $20^{\text {th }}$ century was led by efficiency improvements in commercial solar panels, mostly built with crystalline silicon or cadmium telluride cells [88]-[93]. Cell efficiency improvements have led to a greater focus on balance of system (BOS) costs in the second decade of the $21^{\text {st }}$ century [94]. BOS is a general term encompassing non-module costs of solar PV 
installation including siting, mounting, inverters, cables, permitting, grid connection, and so on [95]. The cost declines associated with advancements during this period have been remarkable. In the past decade, a globally-weighted average of utility scale solar PV project costs has decreased from \$4,621/kW in 2010 to just $\$ 1,210$ in 2018 [81], and solar is now the fastest growing energy source globally. Future technological and cost improvements will come from both solar cell efficiency improvements and reductions in soft costs that make up balance of system [96]-[99].

Lastly, a major driver in reducing both hard and soft costs of solar generation for rooftop applications was the California Solar Initiative (“CSI”) rebate program [100]. Between 2007 and 2016, the CSI budget exceeded \$2.1 billion with a goal of installing over 1.9 GW of new solar capacity. Rebates were given to homeowners based on their utility territory, system size, and other factors; importantly, these rebates had a logical step-down over time based on the aggregate MW installed to date as described in Figure 8. This had the result of providing a known level of support that reduced as the industry matured and played a large role in driving the costs down for the country as a whole.

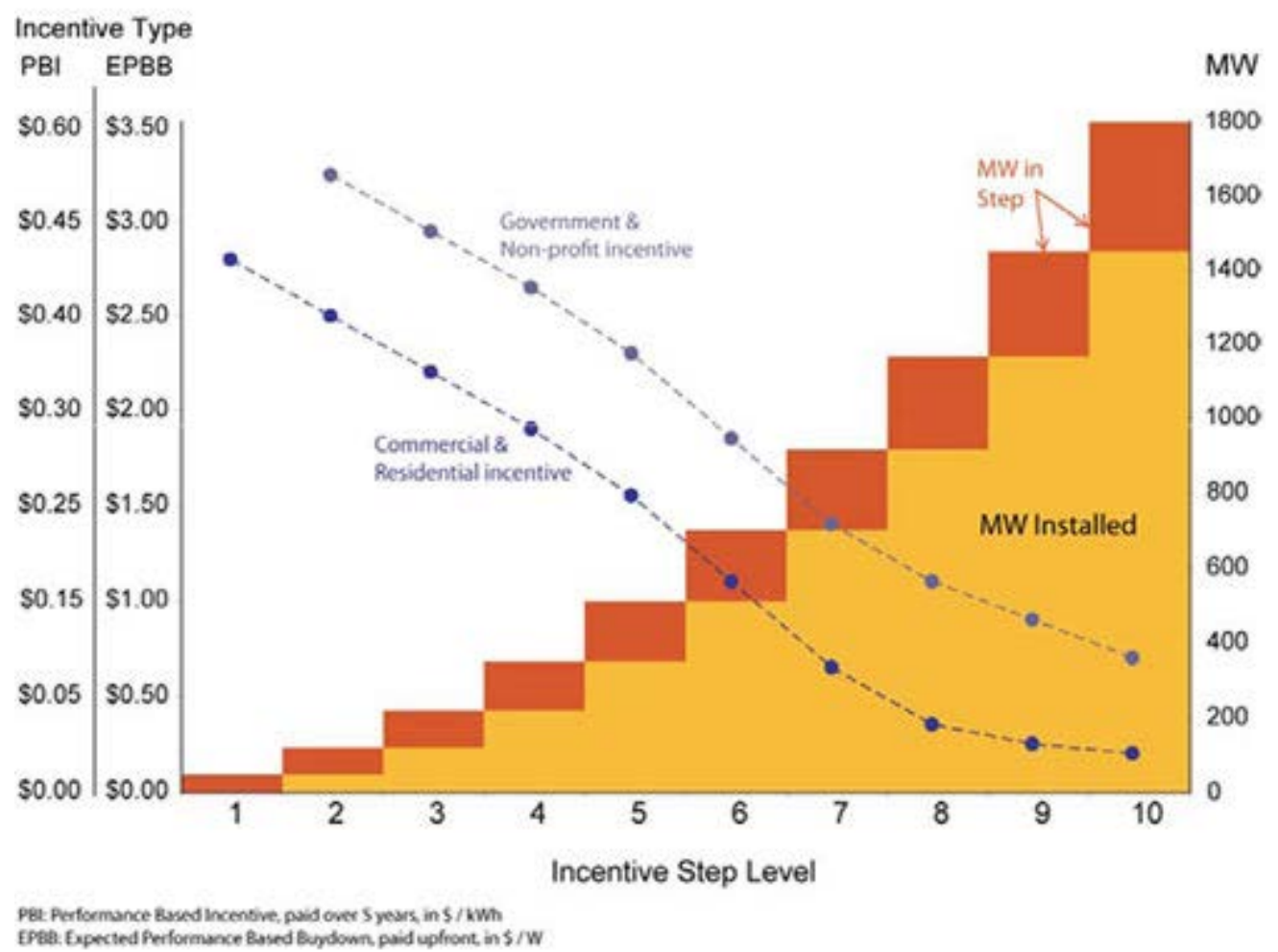

Figure 8 Structure of California Solar Initiative incentive program [101].

The advancement of clean energy in recent decades was characterized by a combination of governmentfunded financial support policies and substantial research and development activities. Wind and solar technologies have led global growth during this period of time. As commercial deployments gained momentum, cost reductions from economies of scale and technological advancements pushed the industries forward. Clean energy technologies are now offering prices that are competitive with or beat conventional energy sources in many markets around the globe. This new reality is rapidly and dramatically reshaping clean energy policy and markets. 


\section{Present day: Economic competitiveness}

The cost declines described in the previous section have led to clean energy competing on cost with historically dominant conventional energy sources. This is fundamentally reshaping the market landscape as suppliers are now choosing to invest in clean energy over alternatives without subsidies or mandates. On the retail side of the market, increased competitiveness has given new leverage to local government entities on behalf of their citizens and corporate energy users in determining the environmental attributes of their energy consumption. This section describes how technology improvements have led to renewables competing with other energy sources on cost, and how this has affected procurement processes and energy markets.

\subsection{Clean energy competitiveness}

Policies designed to stimulate early growth are now being phased out as technologies have matured and become cost-competitive. Policymakers and market participants are shifting towards procurement mechanisms designed to facilitate and enhance the economic competitiveness of clean energy. For example, feed-in tariffs often rely on remuneration models that are set administratively to ensure earlystage growth by guaranteeing investment recovery to owners [102]-[104]. Once costs dropped to the threshold where clean energy investments would occur without a subsidy, policymakers began shifting from administratively-set to competitively-determined prices.

Given this new competitive landscape, clean energy auctions have emerged as a popular policy alternative that allows policymakers to incorporate public energy goals within a competitive process [105]-[108]. Compared to a feed-in tariff, policymakers have found they can exercise better volume control to manage impacts on the grid while achieving efficient price discovery through auctions [109]. The International Renewable Energy Agency (IRENA) has documented roughly 100 gigawatts (GW) of solar and 40 GW of wind awarded through auctions from 2016-2018 alone, with 100 countries having implemented at least one renewable energy auction by 2019 [110]. While the large majority of auction awards have gone to solar PV and wind projects, some auctions are designed to be technology neutral among clean energy sources, and a few GW of awards have gone to other technologies including biomass, biogas, concentrated solar, and small hydro [111].

With clean energy auctions surging in popularity around the world, careful consideration to design specifics is required to achieve satisfactory levels of competition, price discovery and timely delivery. Many factors go into determining an optimal auction design, some of which vary depending on the local market and policy objectives [112]-[115]. Key design elements include the volume, timing, location, technology, remuneration, bid format, and pre-qualification requirements. Policymakers may also desire that projects locally source materials and labor where possible. However, it becomes difficult to maintain local input requirements if they are more expensive and result in higher bid prices. Trade-offs in auction design involve determining the important elements to be administratively-specified, while not being overly prescriptive so that participants have sufficient flexibility to develop efficient bids. Auction designs that are too prescriptive will reduce participation via overly burdensome requirements. A design that is too vague will create unnecessary risk for bidders and similarly reduce participation. Appropriately balancing these design elements is a key factor in determining the overall success of auction implementation [116], [117].

The technological development and scale economies described in the previous section along with more competitive procurement processes can be observed through clean energy transaction prices. A globallyaveraged index of clean energy auction clearing prices has declined from nearly \$250/MWh in 2010 to \$60/MWh in 2018 for solar, and from \$80/MWh to \$55/MWh over the same period for wind, in U.S. 
dollars [110]. Recent prices from bilateral power purchase agreements (PPA) tracked in the U.S. for wind and solar energy show similar trends to the global average but significantly lower levels in recent years. U.S. PPA prices in 2018 averaged around \$20/MWh for both wind and solar projects [30], [118]. These prices are competitive with or lower than reported values for conventional electricity technologies, including coal, natural gas, and nuclear [81], even in markets without explicit clean energy subsidies. Bottom-up engineering and financial analyses that produce levelized cost metrics for comparison across technologies show similar results [48], [119]. Notably, these metrics show wind and solar are currently the cheapest electricity generation technologies in over 2/3 of the world's market [120]. Unsurprisingly, electricity utilities are planning on wind and solar to be major sources of new energy in coming decades [121]-[128].

In addition to clean energy now being a competitive option for new investment, the relatively rapid decrease in clean energy technology costs has put pressure on existing power plants. In many local markets, the levelized cost of energy for building new wind or solar generation is currently lower than the fuel and maintenance costs of running existing power plants [129], [130]. Power plants that rely on short term spot markets for their revenue are especially at risk. The U.S. in particular is characterized by marginal cost-based electricity markets with significant merchant capacity relying on spot market revenues. Low electricity prices from renewable energy along with low-cost natural gas are accelerating the retirement of merchant coal and nuclear plants in these markets, stimulating a transition towards new energy sources. For example, U.S. coal capacity fell 23\% from 2011-2019, decreasing by 73 GW as plants retired or converted to natural gas [131]. Similarly, many nuclear power plants are at risk and suffering from the same economic forces [132].

The economic mechanism behind spot market price decreases is referred to as the merit order effect, graphically displayed in Figure 8. Prices in these markets are determined by short run marginal costs of generation. Wind and solar have significantly lower marginal costs compared to other technologies because they don't require fuel and are placed at the bottom of the short run supply stack, represented as the green portion of supply curve 2. An increase in wind and/or solar shifts the supply curve to the right in any given time period. Some previously-scheduled generators are turned off, and the remaining generators receive less market revenue due to the lower price. The merit order effect has been welldocumented in a large body of scientific literature [133]-[143]. In the past decade, empirical studies have found that each gigawatt-hour increase in wind and solar is approximately associated with market price decreases ranging from 1-5 U.S. dollars per megawatt-hour, depending on the particular market and time period.

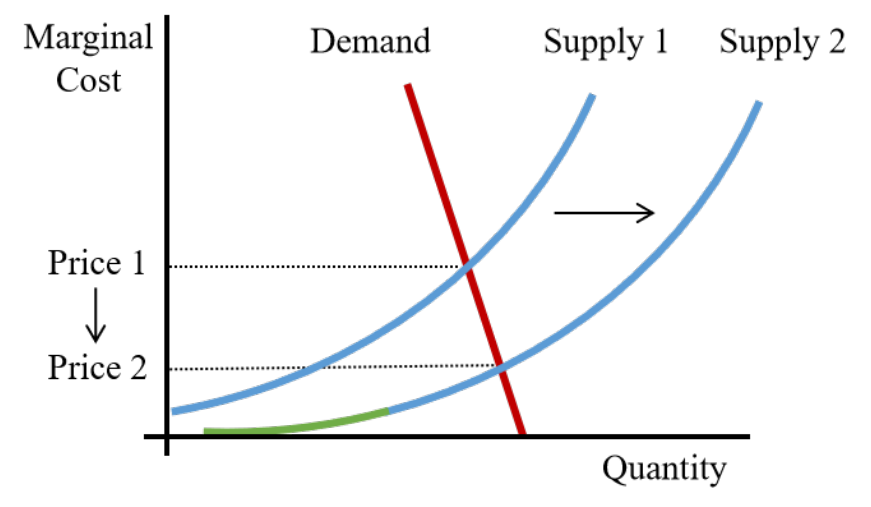

Figure 9 Merit-order effect of renewable energy growth depicted as the green portion of supply curve 2. 


\subsection{Industry transformation}

Technological innovation and the economic competitiveness of clean energy has significant implications for the industrial organization of the electricity sector. Some parts of the industry are becoming more decentralized, including the ownership of generation and distributed resources, while others are trending towards centralization, including transmission network management. On one hand, cost reductions in clean energy have provided new options for energy consumers, including individuals, local governments and corporations. On the other hand, clean energy is accelerating the expansion of centralized market operators and ownership consolidation of conventional assets, including transmission and large centralized power plants.

The shift from large centralized power generation towards combined cycle gas turbines and clean energy technologies is eroding the economies of scale and natural monopoly rationale for generation ownership [144]-[149]. The emergence of third-party owners with competing technology and smaller-scale assets is challenging established large utility business models [150]-[152]. It is also blurring traditional lines between assets on the high voltage power system and the distribution system. System operators, regulators, and integrated utilities around the world are adjusting their market rules to accommodate rapidly growing shares of distributed assets on low voltage networks that collectively have a significant impact on grid operation [153]-[155]. In this environment, energy consumers are more able assert their preferences in purchasing decisions. Distributed generation is an affordable option for an increasing number of households, with the majority of growth coming from small-scale and rooftop solar systems [156], [157]. Local governments are getting involved to make purchasing decisions on behalf of their citizens in the form of community choice aggregation, often with the goal of accelerating their shift towards clean energy sources [158].

Competitive costs and desires for improved sustainability are leading large corporate energy users to procure an increasing amount of renewable energy. There are a variety of ways companies are procuring energy, but much of it is sourced directly through power purchase agreements with the plant owner [159]-[162]. Corporate consumers of renewable energy are getting increasingly organized to share knowledge and improve their collective bargaining power. This includes the establishment of "RE100", a global club of large companies committed to sourcing $100 \%$ of their energy needs by renewables, which at the end of 2018 had 155 company members with a combined revenue greater than US\$4.5 trillion, over $5 \%$ of global gross domestic product [163].

Despite the technological and economic forces shifting the electricity sector towards decentralization, there is concurrently a trend towards centralization of large-scale generation ownership. The challenges that low marginal cost renewable energy and natural gas plus growing distributed energy are placing on conventional power plants is accelerating the consolidation of asset ownership to manage increased risks and lower returns [164]-[169]. There is some empiric evidence that increased operational efficiencies from older power plants have been achieved from recent consolidation because larger owners have more resources to improve their scheduling and outage management procedures [170].

The tasks of short term market scheduling and network management are also becoming increasingly consolidated [171]-[177]. This is partly due to improvements in computing, data storage, and automation reducing transaction costs for improved efficiencies by centralizing these tasks over larger market territories and unlocking gains from trade [178]-[185]. Figure 9 shows the growth over time in day-ahead and real-time markets with third party network operators in the United States and Europe. Clean energy has accelerated this trend by increasing the need for network balancing between wind and solar resources and energy consumers [186]-[188]. In the United States, the markets first appeared in population centers on the east and west coasts plus Texas. More recently, markets have expanded into regions with large 
wind and solar resources but lower populations, including recent growth by the Southwest Power Pool (SPP) and the California Independent System Operator (CAISO) territories [189]-[191].

Decades of stimulus policy, research, and development have made clean energy technologies economically competitive with conventional energy. This has led to significant reductions in observed prices from procurement auctions, bilateral contracts, and short-term markets. Clean energy competitiveness is transforming industries and market structure. Utility business models are evolving as large power plants experience increased competition from clean energy. At the same time, network management and supply scheduling through short term markets are becoming more centralized. The territories of these markets are increasingly expanding and becoming interconnected in response to increased balancing needs from renewable energy resources. In the final section, we look forward and discuss market and policy trends as clean energy grows into the future.
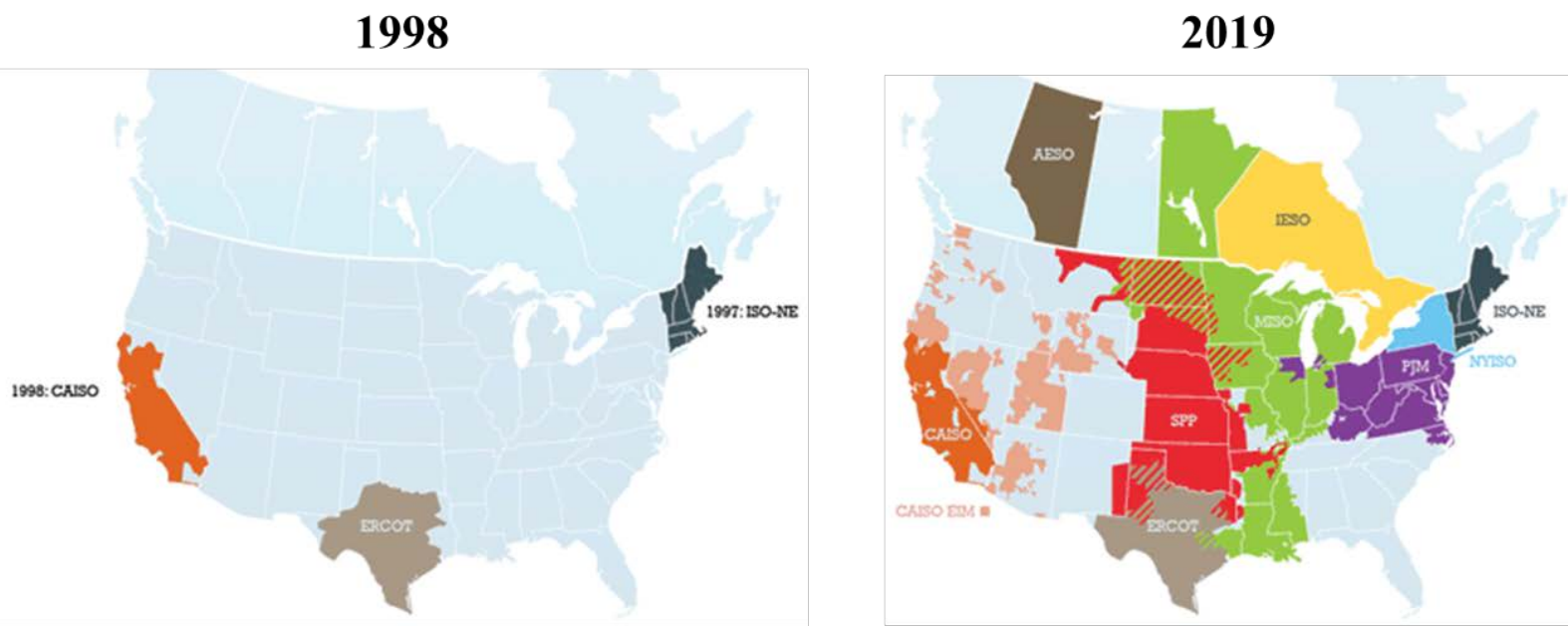

1990's

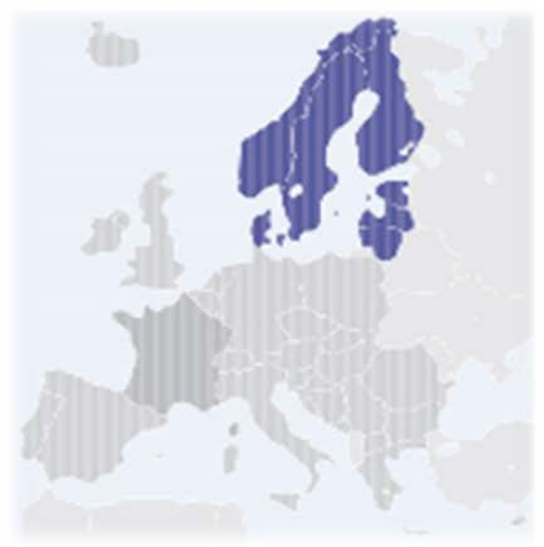

2015

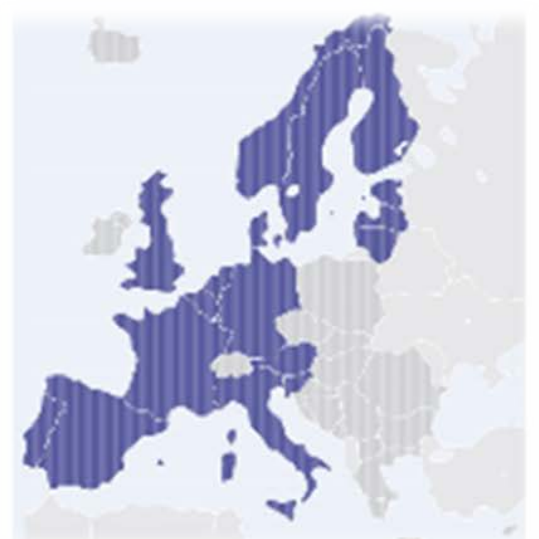

Figure 10 Growth in real time markets with third party transmission operators, United States and Europe [192], [193]. 


\section{Looking forward: Integrating high clean energy levels}

We close this chapter with a discussion of the market and policy characteristics necessary in a high clean energy future. The success to date in the growth and economic competitiveness of clean energy has emboldened policymakers to further increase clean energy targets. This includes goals in certain jurisdictions requiring future clean energy production levels above $50 \%$ and in some cases approach or reach $100 \%$. These policy developments have prompted new thinking about market reforms and integration technologies to accommodate high clean energy levels. Doing so involves technologies to make the electricity system more flexible to adapt to new uncertainties and variation inherent in wind and solar generation. Flexibility strategies include market reforms to take advantage of clean energy's inherent flexibility, increase energy storage, and improve demand side participation.

Jurisdictions are extending and raising renewable energy targets now that technologies have matured and are cost competitive in many markets. The European Union (EU) is well on its way to meet its near term target of $20 \%$ renewable energy by 202. Nearly half of EU countries have met this goal early, and 5 countries are over 30\%, with Sweden at 55\% [194]. In the U.S., most states have met or exceeded their renewable energy targets, and many have raised them in recent years [31]. Leading examples include 100\% clean energy goals in California, Hawaii, New Mexico, New York, and Washington [195], [196]. Large U.S. electric utilities are also announcing aggressive clean energy targets. MidAmerican Energy in the central U.S. will provide customers with $100 \%$ renewable electricity by 2020, Xcel Energy has committed to eliminating $100 \%$ of its carbon emissions by 2050, Platte River Power Authority will eliminate all emissions by 2030, and Consumers Energy plans to cut carbon emissions $80 \%$ by 2040 [197], [198]. These aggressive targets have spurred researchers to think more seriously about policies and market design to manage high renewable electricity systems.

Operational dynamics will change as electricity systems integrate larger shares of clean energy. More specifically, operators of systems with high renewables will need more flexibility to respond to the variable generation patterns of wind and solar [199]-[210]. The broad literature on this topic shows system flexibility can be enhanced at essentially any point in the value chain. This includes supply side flexibility through dynamic management of conventional generation [211]. Flexibility can also be enhanced through the addition of energy storage, and through smarter incentives and technologies for energy consumption.

Clean energy technologies themselves can provide flexibility to system operators. These will be among the lowest-cost sources of early flexibility on high renewable systems as they don't require signficant new capital investments. For example, the inverters on solar PV plants can be actively managed to provide flexibility services to the grid. This can provide broad value to the energy market by mitigating system ramps, reducing uncertainty, and replacing more expensive dispatchable generation [212], [213]. Furthermore, PV plants can provide fast-response services including spinning reserves, frequency response, variability smoothing, voltage support, and frequency regulation [214], [215]. In fact, modern inverters on PV plants under automated generator control from the operator can perform better than a modern gas turbine [216]. Similarly, variable speed wind turbine technologies and their power converters can be operated to provide intertial response, primary frequency control, and reactive power [217]-[224]. These technological capabilities have been demonstrated, however market rules will need updates to enable the shift in provision of these flexibility services from conventional plants to clean energy technologies [225].

The Hawaiian Electric Companies (HECO) provide the first real example of a utility requiring renewable energy resources to become fully dispatchable. With significant penetration of rooftop solar projects that 
are effectively must-take, HECO forecast increasing levels of curtailment across its system. Complicating this factor is the nature of the system itself - multiple islands that are not interconnected, requiring each to balance its load and resources independently. Several islands projected upwards of 20\% curtailment for new renewable resources. HECO's solution is the creation of a new contracting model the Renewable Dispatchable Generation (RDG) PPA [226]. Under this construct, HECO requires all new renewable resources to be fully dispatchable by the utility. In exchange, the developer receives a fixed monthly payment, reflective of their guaranteeing availability and dispatchability of the resource. HECO has executed 262 MW of projects as of December 2018 [227], and will be issuing RFPs totaling over 900 MW in fall 2019 under the RDG model [228].

Energy storage is another technology category that will provide broad flexibility services to a high clean energy grid [229]-[231]. Storage technologies have undergone rapid technological development in recent years. A globally-weighted average of Lithium-ion battery prices shows a decrease from 1,160 USD/kWh in 2010 to only 176 USD/kWh in 2018 [232]. The United States is the early global leader for energy storage deployment. Figure 10 displays the top 15 countries for large-scale storage capacity, excluding pumped hydro storage. The thermal storage category largely consists of molten salt at concentrated solar plants used to store collected energy for use in the evening. Electro-chemical storage consists of a variety of battery technologies. Leading countries in battery installations include the United States, followed by Australia, Germany, China, Japan, and South Korea. The data suggests clean energy systems can be operated today without significant levels of storage, since some countries with high penetrations of clean energy are not on this list. However, research suggests storage will most likely be a necessary component of all future clean energy systems [233].

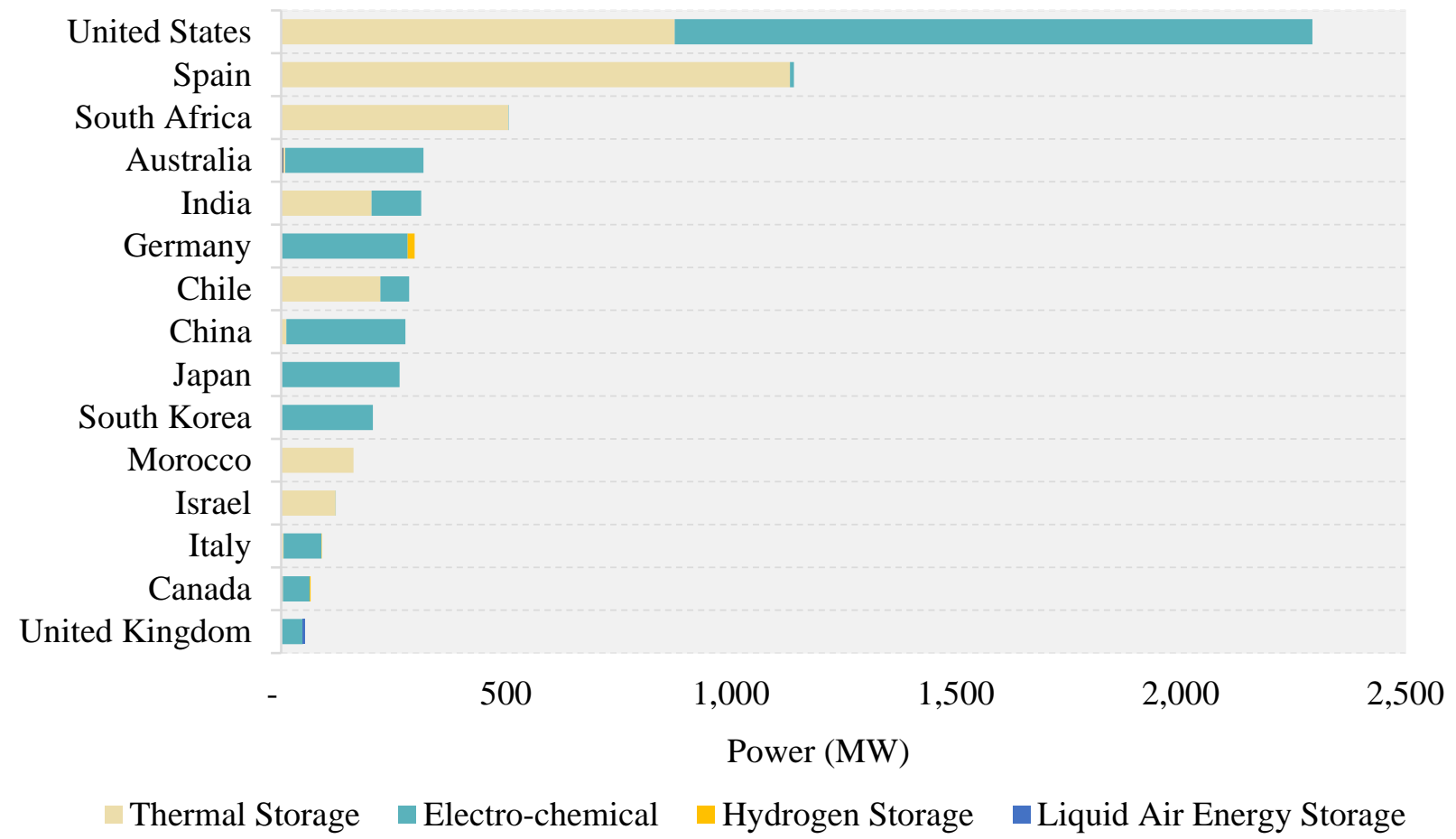

Figure 11 Leading countries for energy storage deployment, excluding pumped hydro [234].

Similar to storage, researchers are working on commercializing a range of technologies that convert excess electricity to gases and petroleum-like liquids [235]-[238]. Referred to broadly as "power-to-gas" 
or "power-to-liquid" (or more generally as "power-to-X"), these technologies promise new flexibility options for excess renewable energy. The first step often involves the production of hydrogen gas using electricity and water via electrolysis, which can then be fed into a variety of useful applications in the chemicals or transportation sectors, especially if additional hydrogen infrastructure is built [239]-[242]. Next, captured carbon dioxide can be brought in and chemically-combined with hydrogen gas to produce synthetic methane, which could be substituted in any application using natural gas [243]-[245]. An alternative process can use captured carbon dioxide with renewable-produced hydrogen to make synthetic petroleum-like liquids. This "liquid sunshine” which would have wide use in current and future transportation systems [246]-[250]. Further research and commercialization is needed, however powerto-X technologies present a promising opportunity to couple renewable electricity with other energybased sectors needing decarbonization, including heating, transportation, and chemicals production. They also offer potential for long-term seasonal storage through the possibility of converting hydrogen back into electrical energy [251], [252].

Active participation by demand is also an important component for increasing system flexibility and managing large amounts of clean energy. Broadly referred to as demand response, this class of technologies and programs can involve sending price signals to customers that vary to reflect system conditions. It also includes incentive programs the provide utilities direct control over energy consumption during periods when demand reduction benefits the system [253]. From an economic efficiency perspective, improving demand response in electricity markets will eliminate deadweight loss and achieve savings for consumers [254]-[256]. Well-designed dynamic pricing programs will enhance flexibility and renewable integration without additional market intervention. Periods of surplus renewable energy would depress prices and incent consumers to increase consumption, while low renewable energy output will cause higher prices that incent conservation. Alternatively, operator- or utility-managed programs can be deployed to integrate renewables and achieve the same outcome indirectly [257]-[260].

The future of policies and markets for clean energy will include a significant focus on support mechanisms to enable large amounts of variable wind and solar energy through improvements to system flexibility. Market operators have and will continue to expand their balancing areas to help manage large scale flows of clean power. Tapping into the inherent flexibility of the existing generation fleet is another low-cost option, as it only requires regulatory and market redesign and not large amounts of additional physical capital. At high levels, energy storage and innovative demand side solutions will be a necessary part of the toolkit for managing future levels of clean energy. These topics are all promising and important areas for researchers working on energy technology solutions. As the energy transition continues, this review makes clear that clean energy technlogies should evolve to replace all the system services historically provided by the fossil fleet.

\section{Conclusion}

Public policy and markets have led to clean energy technologies being economically competitive. Decades of early stimulus policies including and public investments in early research and development played an important role in progress to date. Markets structures the industry are evolving in response. Low-cost clean energy has put economic pressure on conventional power generation, accelerating retirement schedules. Network operators are expanding their territories to manage the increasingly decentralized nature of energy supply, since wind and solar resources are often located farther away from energy consumption. The rapid growth in clean energy in recent years will likely accelerate, given today's competitive environment and the policy support for continued deployment. Future systems with high clean energy levels will require supporting resources and strategies so that operators have sufficient flexibility to manage the dynamic nature of a clean energy system. 
This chapter has sampled the vast online literature on clean energy policies and markets. In doing so, it tells the story of past, present, and likely future developments of policies and market structures for technology researchers in this field. Current and future research should prioritize identifying new strategies and reducing costs for clean energy enabling technologies that improve system flexibility. It should also focus on new market structures necessary to efficiently value new services required in a clean energy future. In conclusion, the future is bright, and clean energy technology research is as important now as it has ever been.

\section{Disclaimer}

This work is supported by the Department of Energy (DOE) Office of Energy Efficiency and Renewable Energy administered by the Oak Ridge Institute for Science and Education (ORISE) for the DOE. ORISE is managed by Oak Ridge Associated Universities (ORAU) under DOE contract number DESC0014664. All opinions expressed in this paper are the author's and do not necessarily reflect the policies and views of First Solar, DOE, ORAU, or ORISE. The authors and organizations mentioned herein retain license to reproduce, prepare derivative works, distribute copies, and display publicly.

\section{References}

[1] H. V. Singh, R. Bocca, P. Gomez, S. Dahlke, and M. Bazilian, "The energy transitions index: An analytic framework for understanding the evolving global energy system," Energy Strategy Rev., vol. 26, p. 100382, Nov. 2019.

[2] International Renewable Energy Agency (IRENA), International Energy Agency (IEA), and Renewable Energy Policy Network for the 21st Century (REN21), "Renewable energy policies in a time of transition," 2019.

[3] J. Yuan, C. Na, Y. Xu, and C. Zhao, “Feed-In Tariff for Onshore Wind Power in China,” Emerg. Mark. Finance Trade, vol. 52, no. 6, pp. 1427-1437, Jun. 2016.

[4] BE Sustainable Editor, "An overview of the biomass energy policy in China.” .

[5] L.-C. Ye, J. F. D. Rodrigues, and H. X. Lin, "Analysis of feed-in tariff policies for solar photovoltaic in China 2011-2016,” Appl. Energy, vol. 203, pp. 496-505, Oct. 2017.

[6] J. Wang, S. Yang, C. Jiang, Y. Zhang, and P. D. Lund, "Status and future strategies for Concentrating Solar Power in China,” Energy Sci. Eng., vol. 5, no. 2, pp. 100-109, 2017.

[7] C. Böhringer, A. Cuntz, D. Harhoff, and E. Asane-Otoo, "The impact of the German feed-in tariff scheme on innovation: Evidence based on patent filings in renewable energy technologies,” Energy Econ., vol. 67, pp. 545-553, Sep. 2017.

[8] C. Nolden, "Performance and Impact of the Feed-in Tariff Scheme: Review of Evidence,” United Kingdom Department of Energy and Climate Change, 2015.

[9] P. del Río González, "Ten years of renewable electricity policies in Spain: An analysis of successive feed-in tariff reforms,” Energy Policy, vol. 36, no. 8, pp. 2917-2929, Aug. 2008.

[10] P. Milanés-Montero, A. Arroyo-Farrona, and E. Pérez-Calderón, “Assessment of the Influence of Feed-In Tariffs on the Profitability of European Photovoltaic Companies,” Sustainability, vol. 10, no. 10, p. 3427, Oct. 2018.

[11] M. T. García-Alvarez and R. M. Mariz-Pérez, "Analysis of the Success of Feed-in Tariff for Renewable Energy Promotion Mechanism in the EU: Lessons from Germany and Spain,” Procedia - Soc. Behav. Sci., vol. 65, pp. 52-57, Dec. 2012.

[12] R. Mauger, "The voluminous energy transition legal framework in France and the question of its recognition as a branch of law,” Energy Policy, vol. 122, pp. 499-505, Nov. 2018.

[13] H. L. Zhang, T. Van Gerven, J. Baeyens, and J. Degrève, "Photovoltaics: Reviewing the European Feed-in-Tariffs and Changing PV Efficiencies and Costs,” Sci. World J., vol. 2014, 2014. 
[14] A. Orioli, V. Franzitta, A. Di Gangi, and F. Foresta, "The Recent Change in the Italian Policies for Photovoltaics: Effects on the Energy Demand Coverage of Grid-Connected PV Systems Installed in Urban Contexts,” Energies, vol. 9, no. 11, p. 944, Nov. 2016.

[15] Y. Tanaka, A. Chapman, S. Sakurai, and T. Tezuka, "Feed-in Tariff Pricing and Social Burden in Japan: Evaluating International Learning through a Policy Transfer Approach,” Soc. Sci., vol. 6, no. 4, p. 127, Dec. 2017.

[16] A. Chaudhary, C. Krishna, and A. Sagar, "Policy making for renewable energy in India: lessons from wind and solar power sectors," Clim. Policy, vol. 15, no. 1, pp. 58-87, Jan. 2015.

[17] Winston \& Strawn, "Feed-In Tariff Handbook for Asian Renewable Energy Systems,” 2014.

[18] P. Gipe, “India’s 1.1 Billion Move to Feed-in Tariffs,” Renewable Energy World.

[19] S. K. Chatterjee, "The Renewable Energy Policy Dilemma in India: Should Renewable Energy Certificate mechanism compete or merge with the Feed-in-Tariff Scheme?,” Harv. Kennedy Sch. Mossavar-Rahmani Cent. Bus. Gov., p. 61, Aug. 2017.

[20] M. Hymel, “United States’ Experience with Energy-Based Tax Incentives: The Evidence Supporting Tax Incentives for Renewable Energy, the,” Loyola Univ. Chic. Law J., vol. 38, p. 43, 20072006.

[21] Scully Capital and Kutak Rock, "Examination of Federal Financial Assistance in the Renewable Energy Market,” Oct. 2018.

[22] Solar Energy Industries Association (SEIA), “Solar Investment Tax Credit (ITC),” SEIA, 2019. [Online]. Available: /initiatives/solar-investment-tax-credit-itc. [Accessed: 10-Sep-2019].

[23] S. Comello and S. Reichelstein, "The U.S. investment tax credit for solar energy: Alternatives to the anticipated 2017 step-down,” Renew. Sustain. Energy Rev., vol. 55, pp. 591-602, Mar. 2016.

[24] R. Wiser, M. Bolinger, and G. Barbose, "Using the Federal Production Tax Credit to Build a Durable Market for Wind Power in the United States,” Electr. J., vol. 20, no. 9, pp. 77-88, Nov. 2007.

[25] R. Bowers, "Tax credit phaseout encourages more wind power plants to be added by end of year," Today in Energy - U.S. Energy Information Administration (EIA).

[26] BP, “BP Statistical Review of World Energy,” Data, 2018.

[27] M. F. Sherlock, “The Renewable Electricity Production Tax Credit: In Brief,” Congressional Research Service, Nov. 2018.

[28] R. Wiser and M. Bolinger, “2013 Wind Technologies Market Report,” p. 96, 2013.

[29] M. J. Barradale, "Impact of public policy uncertainty on renewable energy investment: Wind power and the production tax credit,” Energy Policy, vol. 38, no. 12, pp. 7698-7709, Dec. 2010.

[30] R. Wiser et al., “2018 Wind Technologies Market Report,” 2019.

[31] G. Barbose, “U.S. Renewables Portfolio Standards: 2019 Annual Status Update,” 2019. .

[32] R. Wiser, K. Porter, and R. Grace, "Evaluating Experience with Renewables Portfolio Standards in the United States,” Mitig. Adapt. Strateg. Glob. Change, vol. 10, no. 2, pp. 237-263, Apr. 2005.

[33] K. Maguire and A. Munasib, "The Disparate Influence of State Renewable Portfolio Standards on Renewable Electricity Generation Capacity,” Land Econ., vol. 92, no. 3, pp. 468-490, Aug. 2016.

[34] T. Igogo, "Essays on metals, energy, and government policies," Thesis, Colorado School of Mines. Arthur Lakes Library, 2020.

[35] A. Koseff, “California approves goal for 100\% carbon-free electricity by 2045,” The Sacramento Bee, 10-Sep-2018.

[36] K. De Leon, "Bill Text - SB-100 California Renewables Portfolio Standard Program: emissions of greenhouse gases.,” 2018. [Online]. Available:

https://leginfo.legislature.ca.gov/faces/billNavClient.xhtml?bill_id=201720180SB100. [Accessed: 10-Sep-2019].

[37] National Conference of State Legislatures (NCSL), "State Renewable Portfolio Standards and Goals,” 2019. [Online]. Available: http://www.ncsl.org/research/energy/renewable-portfoliostandards.aspx. [Accessed: 10-Sep-2019].

[38] Reuters, “China sets renewable power quotas for 2019, 2020,” Reuters, 15-May-2019. 
[39] C. Xuewan and D. Kirton, "China to Introduce Provincial Energy Quotas in Fight Against Renewables Waste,” 16-May-2019. [Online]. Available: https://www.caixinglobal.com/2019-0516/china-to-introduce-provincial-energy-quotas-in-fight-against-renewables-waste101416505.html. [Accessed: 10-Sep-2019].

[40] W. Xiong, D. Zhang, P. Mischke, and X. Zhang, "Impacts of Renewable Energy Quota System on China’s Future Power Sector,” Energy Procedia, vol. 61, pp. 1187-1190, Jan. 2014.

[41] J. Fan, W. Sun, and D.-M. Ren, "Renewables portfolio standard and regional energy structure optimisation in China,” Energy Policy, vol. 33, no. 3, pp. 279-287, Feb. 2005.

[42] International Energy Agency (IEA), "China - Renewable Electricity Quota and Assessment Method (Draft for Opinions),” 2019. .

[43] G. Luo, E. Dan, X. Zhang, and Y. Guo, "Why the Wind Curtailment of Northwest China Remains High,” Sustainability, vol. 10, no. 2, p. 570, Feb. 2018.

[44] S. Zhang, P. Andrews-Speed, and S. Li, "To what extent will China's ongoing electricity market reforms assist the integration of renewable energy?,” Energy Policy, vol. 114, pp. 165-172, Mar. 2018.

[45] D. Elliott, “Green power curtailment in China," Physics World, 17-Jul-2019.

[46] J. Huenteler, T. Tang, G. Chan, and L. D. Anadon, "Why is China's wind power generation not living up to its potential?,” Environ. Res. Lett., vol. 13, no. 4, p. 044001, Mar. 2018.

[47] International Energy Agency (IEA) and International Renewable Energy Agency (IRENA), "Joint Policies and Measures Database,” 2019. [Online]. Available: https://www.iea.org/policiesandmeasures/renewableenergy/. [Accessed: 09-Sep-2019].

[48] Lazard, “Lazard’s Levelized Cost of Energy Analysis-Version 12.0,” p. 20, 2018.

[49] U.S. Department of Energy Federal Energy Management Program (US DOE FEMP), "Biomass for Electricity Generation | WBDG - Whole Building Design Guide,” 15-Sep-2016. [Online]. Available: https://www.wbdg.org/resources/biomass-electricity-generation. [Accessed: 11-Sep2019].

[50] B. Wahlund, J. Yan, and M. Westermark, "Increasing biomass utilisation in energy systems: A comparative study of CO2 reduction and cost for different bioenergy processing options," Biomass Bioenergy, vol. 26, no. 6, pp. 531-544, Jun. 2004.

[51] P. Ralevic, M. Ryans, and D. Cormier, "Assessing forest biomass for bioenergy: Operational challenges and cost considerations,” For. Chron., vol. 86, no. 1, pp. 43-50, Feb. 2010.

[52] J. L. Thompson and W. E. Tyner, "Corn stover for bioenergy production: Cost estimates and farmer supply response,” Biomass Bioenergy, vol. 62, pp. 166-173, Mar. 2014.

[53] Z. Baicha et al., "A critical review on microalgae as an alternative source for bioenergy production: A promising low cost substrate for microbial fuel cells,” Fuel Process. Technol., vol. 154, pp. 104-116, Dec. 2016.

[54] R. Perrin, K. Vogel, M. Schmer, and R. Mitchell, "Farm-Scale Production Cost of Switchgrass for Biomass,” BioEnergy Res., vol. 1, no. 1, pp. 91-97, Mar. 2008.

[55] S. K. Rose et al., "Bioenergy in energy transformation and climate management," Clim. Change, vol. 123, no. 3, pp. 477-493, Apr. 2014.

[56] C. Hepburn, J. Pless, and D. Popp, "Policy Brief—Encouraging Innovation that Protects Environmental Systems: Five Policy Proposals,” Rev. Environ. Econ. Policy, vol. 12, no. 1, pp. 154-169, Feb. 2018.

[57] History.com, “OPEC enacts oil embargo,” 2019. [Online]. Available: https://www.history.com/this-day-in-history/opec-enacts-oil-embargo. [Accessed: 12-Sep-2019].

[58] Rapid Transition Alliance, "From Oil Crisis to Energy Revolution - How Nations Once Before Planned to Kick the Oil Habit,” Resilience, 17-Apr-2019. [Online]. Available: https://www.resilience.org/stories/2019-04-17/from-oil-crisis-to-energy-revolution-how-nationsonce-before-planned-to-kick-the-oil-habit/. [Accessed: 12-Sep-2019].

[59] F. N. Laird and C. Stefes, "The diverging paths of German and United States policies for renewable energy: Sources of difference,” Energy Policy, vol. 37, no. 7, pp. 2619-2629, Jul. 2009. 
[60] United States Department of Energy (US DOE), “A Brief History of the Department of Energy,” Energy.gov. [Online]. Available: https://www.energy.gov/management/officemanagement/operational-management/history/brief-history-department-energy. [Accessed: 12Sep-2019].

[61] National Renewable Energy Laboratory (NREL), "Laboratory History,” 2019. [Online]. Available: https://www.nrel.gov/about/history.html. [Accessed: 12-Sep-2019].

[62] L. M. Murphy, "Wind loading on tracking and field-mounted solar collectors," SERI-TP-632-958, 6889663, Dec. 1980.

[63] G. Jones and L. Bouamane, “Power from Sunshine’: A Business History of Solar Energy,” p. 89.

[64] J. Wittry, "Wind Energy Research Reaps Rewards,” National Aeronautics and Space Administration (NASA), 31-May-2006. [Online]. Available: https://www.nasa.gov/vision/earth/technologies/wind_turbines.html. [Accessed: 12-Sep-2019].

[65] J. K. Kaldellis and D. Zafirakis, "The wind energy (r)evolution: A short review of a long history," Renew. Energy, vol. 36, no. 7, pp. 1887-1901, Jul. 2011.

[66] R. Bointner, S. Pezzutto, G. Grilli, and W. Sparber, "Financing Innovations for the Renewable Energy Transition in Europe,” Energies, vol. 9, no. 12, p. 990, Dec. 2016.

[67] International Energy Agency, "History.” [Online]. Available: https://www.iea.org/about/history/. [Accessed: 12-Sep-2019].

[68] J. I. Lewis and R. H. Wiser, "Fostering a renewable energy technology industry: An international comparison of wind industry policy support mechanisms," Energy Policy, vol. 35, no. 3, pp. 18441857, Mar. 2007.

[69] J. Vestergaard, L. Brandstrup, and R. D. Goddard, "A Brief History of the Wind Turbine Industries in Denmark and the United States," 2004.

[70] P. Karnøe, "Technological innovation and industrial organization in the Danish wind industry," Entrep. Reg. Dev., vol. 2, no. 2, pp. 105-124, Jan. 1990.

[71] K. Ericsson and S. Werner, "The introduction and expansion of biomass use in Swedish district heating systems,” Biomass Bioenergy, vol. 94, pp. 57-65, Nov. 2016.

[72] R. Björheden, "Development of Bioenergy from Forest Biomass - a Case Study of Sweden and Finland,” 2017.

[73] S. Jacobsson and V. Lauber, "The politics and policy of energy system transformation-explaining the German diffusion of renewable energy technology,” Energy Policy, vol. 34, no. 3, pp. 256276, Feb. 2006.

[74] R. Garud and P. Karnøe, "Bricolage versus breakthrough: distributed and embedded agency in technology entrepreneurship,” Res. Policy, vol. 32, no. 2, pp. 277-300, Feb. 2003.

[75] W. McDowall, P. Ekins, S. Radošević, and L. Zhang, "The development of wind power in China, Europe and the USA: how have policies and innovation system activities co-evolved?," Technol. Anal. Strateg. Manag., vol. 25, no. 2, pp. 163-185, Feb. 2013.

[76] K. Rohrig et al., "Powering the 21st century by wind energy—Options, facts, figures," Appl. Phys. Rev., vol. 6, no. 3, p. 031303, Aug. 2019.

[77] M. Bolinger and R. Wiser, "Understanding Trends in Wind Turbine Prices Over the Past Decade," 2011.

[78] R. Wiser et al., "Expert elicitation survey on future wind energy costs," Nat. Energy, vol. 1, no. 10, p. 16135, Oct. 2016.

[79] International Energy Agency (IEA), “Energy Technology RD\&D,” 2019. [Online]. Available: https://www.iea.org/statistics/rdd/. [Accessed: 12-Sep-2019].

[80] MacroTrends, “Crude Oil Prices - 70 Year Historical Chart,” 2019. [Online]. Available: https://www.macrotrends.net/1369/crude-oil-price-history-chart. [Accessed: 12-Sep-2019].

[81] International Renewable Energy Agency (IRENA), "Renewable Power Generation Costs in 2018," May 2019.

[82] E. Lantz and M. Hand, "Past and Future Cost of Wind Energy: Preprint,” p. 10. 
[83] D. Roberts, “These huge new wind turbines are a marvel. They're also the future.,” Vox, 08-Mar2018. [Online]. Available: https://www.vox.com/energy-andenvironment/2018/3/8/17084158/wind-turbine-power-energy-blades. [Accessed: 13-Sep-2019].

[84] J. Deign, “An Illustrated Guide to the Growing Size of Wind Turbines,” 10-Aug-2017. [Online]. Available: https://www.greentechmedia.com/articles/read/an-illustrated-guide-to-the-growingsize-of-wind-turbines. [Accessed: 13-Sep-2019].

[85] Chrisdesign, "Public Domain Clip Art Image | wind turbine,” 05-Nov-2012. [Online]. Available: http://www.publicdomainfiles.com/show_file.php?id=13530417618276. [Accessed: 13-Sep-2019].

[86] “Free Image on Pixabay - Eiffel Tower, Paris, Silhouette.” [Online]. Available: https://pixabay.com/vectors/eiffel-tower-paris-silhouette-307022/. [Accessed: 13-Sep-2019].

[87] F. Meneguzzo, R. Ciriminna, L. Albanese, and M. Pagliaro, "The great solar boom: a global perspective into the far reaching impact of an unexpected energy revolution," Energy Sci. Eng., vol. 3, no. 6, pp. 499-509, 2015.

[88] G. Kavlak, J. McNerney, and J. E. Trancik, "Evaluating the causes of cost reduction in photovoltaic modules,” Energy Policy, vol. 123, pp. 700-710, Dec. 2018.

[89] S. Kurtz et al., "Historical Analysis of Champion Photovoltaic Module Efficiencies," IEEE J. Photovolt., vol. 8, no. 2, pp. 363-372, Mar. 2018.

[90] National Renewable Energy Laboratory (NREL), "Best Research-Cell Efficiency Chart | Photovoltaic Research.” [Online]. Available: https://www.nrel.gov/pv/cell-efficiency.html. [Accessed: 13-Sep-2019].

[91] E. Wesoff, “First Solar Reaches 16.3\% Efficiency in Production PV Modules,” 04-May-2015. [Online]. Available: https://www.greentechmedia.com/articles/read/first-solar-is-reaching-16-3efficiency-in-production-pv-modules. [Accessed: 13-Sep-2019].

[92] "First Solar Achieves New World Conversion Efficiency Record For Cadmium-Telluride Solar Cells,” CleanTechnica, 09-Feb-2015. [Online]. Available:

https://cleantechnica.com/2015/02/09/first-solar-achieves-new-world-conversion-efficiencyrecord-cadmium-telluride-solar-cells/. [Accessed: 13-Sep-2019].

[93] J. Liu, Y. Yao, S. Xiao, and X. Gu, "Review of status developments of high-efficiency crystalline silicon solar cells,” J. Phys. Appl. Phys., vol. 51, no. 12, p. 123001, Feb. 2018.

[94] A. M. Elshurafa, S. R. Albardi, S. Bigerna, and C. A. Bollino, "Estimating the learning curve of solar PV balance-of-system for over 20 countries: Implications and policy recommendations,” $J$. Clean. Prod., vol. 196, pp. 122-134, Sep. 2018.

[95] R. Fu, D. Feldman, R. Margolis, M. Woodhouse, and K. Ardani, "U.S. Solar Photovoltaic System Cost Benchmark: Q1 2017,” Renew. Energy, p. 73.

[96] S. Battersby, "News Feature: The solar cell of the future," Proc. Natl. Acad. Sci. U. S. A., vol. 116, no. 1, pp. 7-10, Jan. 2019.

[97] P. Ralon, “Global renewable energy cost trends,” International Renewable Energy Agency (IRENA), 2018.

[98] M. Munsell, “10 Trends That Will Shape the Global Solar Market in 2018,” 31-Jan-2018.

[99] J. Bailey, "Getting PV to 2 cents per kWh: Panel vs balance of system costs," Energy Narrative, 26-Feb-2018. .

[100] “About the California Solar Initiative (CSI) - Go Solar California.” [Online]. Available: https://www.gosolarcalifornia.org/about/csi.php. [Accessed: 30-Sep-2019].

[101] “California Solar Initiative (CSI) - Rebate Levels.” [Online]. Available: https://www.gosolarcalifornia.org/csi/rebates.php. [Accessed: 30-Sep-2019].

[102] T. Couture and Y. Gagnon, "An analysis of feed-in tariff remuneration models: Implications for renewable energy investment,” Energy Policy, vol. 38, no. 2, pp. 955-965, Feb. 2010.

[103] P. Bull, N. Long, and C. Steger, "Designing Feed-in Tariff Policies to Scale Clean Distributed Generation in the U.S.,” Electr. J., vol. 24, no. 3, pp. 52-58, Apr. 2011. 
[104] T. D. Couture, K. Cory, C. Kreycik, and E. Williams, "Policymaker's Guide to Feed-in Tariff Policy Design,” National Renewable Energy Lab. (NREL), Golden, CO (United States), NREL/TP-6A2-44849, Jul. 2010.

[105] M. D. Leiren and I. Reimer, "Historical institutionalist perspective on the shift from feed-in tariffs towards auctioning in German renewable energy policy,” Energy Res. Soc. Sci., vol. 43, pp. 33-40, Sep. 2018.

[106] C. Warren, “As Feed-In Tariffs Wane, Auctions Are Enabling the Next Wave of Solar Cost Improvements," Greentech Media, 10-May-2016.

[107] O. W. Fitch-Roy, D. Benson, and B. Woodman, "Policy Instrument Supply and Demand: How the Renewable Electricity Auction Took over the World,” Polit. Gov., vol. 7, no. 1, pp. 81-91, Mar. 2019.

[108] International Renewable Energy Agency (IRENA) and Clean Energy Ministerial (CEM), "Renewable Energy Auctions - A Guide to Design,” 2015.

[109] M. Gephart, C. Klessmann, and F. Wigand, "Renewable energy auctions - When are they (cost)effective?,” Energy Environ., vol. 28, no. 1-2, pp. 145-165, Mar. 2017.

[110] International Renewable Energy Agency (IRENA), "Renewable Energy Auctions: Status and Trends Beyond Price,” 2019.

[111] REN21, “Renewables 2019 Global Status Report,” 2019.

[112] P. del Río, "Designing auctions for renewable electricity support. Best practices from around the world,” Energy Sustain. Dev., vol. 41, pp. 1-13, Dec. 2017.

[113] P. del Río and P. Linares, "Back to the future? Rethinking auctions for renewable electricity support,” Renew. Sustain. Energy Rev., vol. 35, pp. 42-56, Jul. 2014.

[114] M.-C. Haufe and K.-M. Ehrhart, “Auctions for renewable energy support - Suitability, design, and first lessons learned,” Energy Policy, vol. 121, pp. 217-224, Oct. 2018.

[115] J. Kreiss, K.-M. Ehrhart, and M.-C. Haufe, "Appropriate design of auctions for renewable energy support - Prequalifications and penalties,” Energy Policy, vol. 101, pp. 512-520, Feb. 2017.

[116] J. Winkler, M. Magosch, and M. Ragwitz, "Effectiveness and efficiency of auctions for supporting renewable electricity - What can we learn from recent experiences?,” Renew. Energy, vol. 119, pp. 473-489, Apr. 2018.

[117] D. Toke, “Renewable Energy Auctions and Tenders: How good are they?,” Int. J. Sustain. Energy Plan. Manag., vol. 8, pp. 43-56, Dec. 2015.

[118] M. Bolinger and J. Seel, "Utility-Scale Solar: Empirical Trends in Technology, Cost, Performance, and PPA Pricing in the United States - 2018 Edition,” Lawrence Berkeley National Lab. (LBNL), Sep. 2018.

[119] Wood Mackenzie, “China renewables competitiveness report 2019,” Aug. 2019.

[120] BloombergNEF, "New Energy Outlook 2019.”

[121] Xcel Energy, "Upper Midwest Integrated Resource Plan: 2020-2034.”

[122] C. Morehouse, "Duke Energy aims for 100\% carbon-free power by 2050,” Utility Dive.

[123] J. St. John, “Consumers Energy to Seek 5GW of Solar by 2030 Under Clean Energy Plan,” Greentech Media, 25-Mar-2019.

[124] I. Gheorghiu, "Cleco, SWEPCO shift coal plant use, target 2.8 GW renewables in latest resource plans," Utility Dive.

[125] I. Gheorghiu, "California ALJ proposes statewide renewable energy procurement for utilities,” Utility Dive.

[126] "Fortis Utilities Take Action to Decrease Greenhouse Gas Emissions and Increase Renewable Energy Use,” Yahoo! Finance.

[127] R. Loken and A. Smith, "An Integrated Resource Plan for Public Service Company of Colorado (PSCo),” Master Sci. Energy Syst. Manag., May 2019.

[128] E. F. Merchant, "Resource Plans Show Some Utilities Are Still Cautiously Investing in Renewables,” 24-May-2018. 
[129] M. Gray, S. Ljungwaldh, L. Watson, and I. Kok, "Powering down coal: Navigating the economic and financial risks in the last years of coal power," Carbon Tracker Initiative, Nov. 2018.

[130] E. Gimon, M. O’Boyle, C. T. M. Clack, and S. McKee, “The coal cost crossover: Economic viability of existinf coal compared to new local wind and solar resources,” Energy Innovation LLC.

[131] M. Greenberg, “Cheap gas, renewables drive US coal plant closures,” S\&P Global Platts Insight, 02-Apr-2019. .

[132] S. Clemmer, J. Richardson, S. Sandra, and D. Lochbaum, “The Nuclear Power Dilemma,” Union of Concerned Scientists.

[133] D. Quint and S. Dahlke, "The impact of wind generation on wholesale electricity market prices in the midcontinent independent system operator energy market: An empirical investigation,” Energy, vol. 169, pp. 456-466, Feb. 2019.

[134] C. Brancucci Martinez-Anido, G. Brinkman, and B.-M. Hodge, "The impact of wind power on electricity prices,” Renew. Energy, vol. 94, pp. 474-487, Aug. 2016.

[135] C. Woo, J. Zarnikau, J. Kadish, I. Horowitz, J. Wang, and A. Olson, “The Impact of Wind Generation on Wholesale Electricity Prices in the Hydro-Rich Pacific Northwest," IEEE Trans. Power Syst., vol. 28, no. 4, pp. 4245-4253, Nov. 2013.

[136] C. K. Woo, I. Horowitz, J. Moore, and A. Pacheco, "The impact of wind generation on the electricity spot-market price level and variance: The Texas experience,” Energy Policy, vol. 39, no. 7, pp. 3939-3944, Jul. 2011.

[137] K. Würzburg, X. Labandeira, and P. Linares, "Renewable generation and electricity prices: Taking stock and new evidence for Germany and Austria,” Energy Econ., vol. 40, pp. S159-S171, Dec. 2013.

[138] H. A. Gil and J. Lin, "Wind Power and Electricity Prices at the PJM Market," IEEE Trans. Power Syst., vol. 28, no. 4, pp. 3945-3953, Nov. 2013.

[139] E. A. Unger, G. F. Ulfarsson, S. M. Gardarsson, and T. Matthiasson, "The effect of wind energy production on cross-border electricity pricing: The case of western Denmark in the Nord Pool market,” Econ. Anal. Policy, vol. 58, Jun. 2018.

[140] J. Seel, A. Mills, and R. Wiser, "Impacts of High Variable Renewable Energy Futures on Wholesale Electricity Prices, and on Electric-Sector Decision Making,” Lawrence Berkeley National Lab (LBNL), 2018.

[141] S. Clò, A. Cataldi, and P. Zoppoli, "The merit-order effect in the Italian power market: The impact of solar and wind generation on national wholesale electricity prices,” Energy Policy, vol. 77, Feb. 2015.

[142] M. Mulder and B. Scholtens, "The impact of renewable energy on electricity prices in the Netherlands,” Renew. Energy, vol. 57, pp. 94-100, Sep. 2013.

[143] Å. G. Tveten, T. F. Bolkesjø, T. Martinsen, and H. Hvarnes, "Solar feed-in tariffs and the merit order effect: A study of the German electricity market,” Energy Policy, vol. 61, pp. 761-770, Oct. 2013.

[144] P. VanDoren, "The Deregulation of the Electricity Industry: A Primer," Cato Institute, Oct. 1998.

[145] C. Winston, “U.S. Industry Adjustment to Economic Deregulation,” J. Econ. Perspect., vol. 12, no. 3, pp. 89-110, Sep. 1998.

[146] T. J. Considine and A. N. Kleit, "Comparing Electricity Deregulation in California and Pennsylvania: Implications for the Appalachain Region,” Appalachain Regional Commission, Jan. 2002.

[147] S. Corneli, S. Kihm, and L. Schwartz, "Electric Industry Structure and Regulatory Responses in a High Distributed Energy Resources Future,” LBNL--1003823, 1237497, Nov. 2015.

[148] D. J. Hess, "Electricity Transformed: Neoliberalism and Local Energy in the United States," Antipode, vol. 43, no. 4, pp. 1056-1077, 2011.

[149] R. Day, "The Rise of Choices and the End of Natural Monopolies,” Greentech Media, 30-Mar2015. 
[150] M. Richter, "Business model innovation for sustainable energy: German utilities and renewable energy,” Energy Policy, vol. 62, pp. 1226-1237, Nov. 2013.

[151] P. Nillesen, M. Pollitt, and E. Witteler, "Chapter 2 - New Utility Business Model: A Global View," in Distributed Generation and its Implications for the Utility Industry, F. P. Sioshansi, Ed. Boston: Academic Press, 2014, pp. 33-47.

[152] B. Hannes and M. Abbott, "Distributed energy: Disrupting the utility business model,” Bain \& Company, Bain Brief, 2013.

[153] International Renewable Energy Agency (IRENA), "Market integration of distributed energy resources: Innovation landscape brief,” p. 24, 2019.

[154] International Renewable Energy Agency (IRENA), "Future role of distribution system operators: Innovation Landscape Brief,” p. 20, 2019.

[155] New York Independent System Operator (NYISO), "Distributed Energy Resources Roadmap for New York’s Wholesale Electricity Markets,” Jan. 2017.

[156] P. Gunjan, "Global Additions in Distributed Generation Capacity to Increase Significantly,” Navigant Research, 03-May-2019. .

[157] J. St. John, “Distributed Energy Poised for 'Explosive Growth’ on the US Grid,” Greentech Media, 21-Jun-2018.

[158] E. J. OShaughnessy, J. S. Heeter, J. Gattaciecca, J. Sauer, K. Trumbull, and E. I. Chen, "Community Choice Aggregation: Challenges, Opportunities, and Impacts on Renewable Energy Markets,” NREL/TP--6A20-72195, 1494285, Feb. 2019.

[159] U. Outka, “'100 Percent Renewable’: Company Pledges and State Energy Law,” Utah Law Rev., vol. 2019, no. 3, pp. 661-708, Jun. 2019.

[160] D. Johnson, "Corporate Procurement of Renewable Energy as a Key Driver in the Decarbonization of the Power Industry,” Duke Univ., p. 58, May 2018.

[161] A. Trivella, D. Mohseni-Taheri, and S. Nadarajah, "Meeting Corporate Renewable Power Targets," 2018.

[162] C. Tang and F. Zhang, "Classification, principle and pricing manner of renewable power purchase agreement,” IOP Conf. Ser. Earth Environ. Sci., vol. 295, p. 052054, Jul. 2019.

[163] RE100 and The Climate Group, "Moving to Truly Global Impact: Influencing renewable energy markets," Nov. 2018.

[164] J. Neville, “Consolidation and Divestment Key Strategies for Utilities,” Infocast, 11-Jan-2019.

[165] S. Ajila, "Consolidation in the Electric Utilities Industry,” Value Line.

[166] J. S. John, "The Top Trends Behind the Growing, Multibillion-Dollar Market for Utility Mergers and Acquisitions,” Greentech Media, 30-May-2016.

[167] P. Maloney, "Despite high-profile denials, power sector M\&A strength to continue,” Utility Dive.

[168] T. Hoium, "Why Consolidation is the Name of the Game in the Utility Space," The Motley Fool, 04-Jun-2016.

[169] F. Domanico, "Concentration in the European electricity industry: The internal market as solution?,” Energy Policy, vol. 35, no. 10, pp. 5064-5076, Oct. 2007.

[170] L. W. Davis and C. Wolfram, "Deregulation, Consolidation, and Efficiency: Evidence from U.S. Nuclear Power," 2011.

[171] E. S. Amundsen and L. Bergman, "Integration of multiple national markets for electricity: The case of Norway and Sweden,” Energy Policy, vol. 35, no. 6, pp. 3383-3394, Jun. 2007.

[172] A. Creti, E. Fumagalli, and E. Fumagalli, "Integration of electricity markets in Europe: Relevant issues for Italy,” Energy Policy, vol. 38, no. 11, pp. 6966-6976, Nov. 2010.

[173] E. Gnansounou and J. Dong, "Opportunity for inter-regional integration of electricity markets: the case of Shandong and Shanghai in East China,” Energy Policy, vol. 32, no. 15, pp. 1737-1751, Oct. 2004.

[174] E. Gnansounou, H. Bayem, D. Bednyagin, and J. Dong, "Strategies for regional integration of electricity supply in West Africa,” Energy Policy, vol. 35, no. 8, pp. 4142-4153, Aug. 2007. 
[175] E. Hooper and A. Medvedev, "Electrifying integration: Electricity production and the South East Europe regional energy market,” Util. Policy, vol. 17, no. 1, pp. 24-33, Mar. 2009.

[176] P.-O. Pineau, "Electricity sector integration in West Africa," Energy Policy, vol. 36, no. 1, pp. 210-223, Jan. 2008.

[177] Y. Wu, "Electricity market integration: Global trends and implications for the EAS region," Energy Strategy Rev., vol. 2, no. 2, pp. 138-145, Sep. 2013.

[178] S. Dahlke, "Integrating electricity markets: Impacts of increasing trade on prices and emissions in the western United States,” ArXiv181004759 Econ Q-Fin, Oct. 2018.

[179] J. Bower, Seeking the single European electricity market : evidence from an empirical analysis of wholesale market prices. Oxford Institute for Energy Studies, 2002.

[180] F. Kalantzis and N. T. Milonas, "Market integration and price dispersion in the European electricity market,” in 2010 7th International Conference on the European Energy Market, 2010, pp. 1-6.

[181] J. Lundgren, J. Hellstrom, and N. Rudholm, "Multinational electricity market integration and electricity price dynamics," in 2008 5th International Conference on the European Electricity Market, 2008, pp. 1-6.

[182] R. Nepal and T. Jamasb, "Interconnections and market integration in the Irish Single Electricity Market,” Energy Policy, vol. 51, pp. 425-434, Dec. 2012.

[183] D. Newbery, G. Strbac, and I. Viehoff, "The benefits of integrating European electricity markets,” Energy Policy, vol. 94, pp. 253-263, Jul. 2016.

[184] I. Soares and P. Pereira da Silva, "EU spot prices and industry structure: assessing electricity market integration,” Int. J. Energy Sect. Manag., vol. 2, no. 3, pp. 340-350, Sep. 2008.

[185] G. Zachmann, "Electricity wholesale market prices in Europe: Convergence?,” Energy Econ., vol. 30, no. 4, pp. 1659-1671, Jul. 2008.

[186] S. Dahlke, "Effects of wholesale electricity markets on wind generation in the midwestern United States,” Energy Policy, vol. 122, pp. 358-368, Nov. 2018.

[187] M. Milligan, B. Kirby, R. Gramlich, and M. Goggin, "Impact of Electric Industry Structure on High Wind Penetration Potential,” NREL/TP-550-46273, 962494, Jul. 2009.

[188] A. Mills and R. Wiser, "Implications of Wide-Area Geographic Diversity for Short- Term Variability of Solar Power,” Lawrence Berkeley National Lab. (LBNL), Berkeley, CA (United States), LBNL-3884E, Aug. 2010.

[189] R. Walton, "CAISO to develop regional day-ahead market for renewables after participant push," Utility Dive, 23-Sep-2019.

[190] R. Walton, "Tri-State joins suite of new participants in Southwest, California energy imbalance markets," Utility Dive, 11-Sep-2019.

[191] R. Kuckro, "Southwest Power Pool launches new market, is poised to double in size," E\&E News, 28-Feb-2014.

[192] “ISO/RTO Council.” .

[193] European Network of Transmission System Operators for Electricity (ENTSO-E), "Market.” [Online]. Available: https://www.entsoe.eu/about/market/. [Accessed: 27-Sep-2019].

[194] S. Fleming, “These 11 EU states already meet their 2020 renewable energy targets,” World Economic Forum, 18-Feb-2019. .

[195] S. Quinton, “To Counteract Trump on Climate, States Set Clean Energy Targets,” Stateline, 02Aug-2019. .

[196] K. Chamberlain, “The '100 percenters' club is growing,” Medium, 24-Apr-2019.

[197] H. K. Trabish, “As 100\% renewables goals proliferate, what role for utilities?,” Utility Dive, 02Apr-2019.

[198] S. Ptacek and S. Carter, "More Utilities Make Big Commitments to Climate Action,” NRDC, 05Mar-2019. 
[199] H. Kondziella and T. Bruckner, "Flexibility requirements of renewable energy based electricity systems - a review of research results and methodologies,” Renew. Sustain. Energy Rev., vol. 53, pp. 10-22, Jan. 2016.

[200] M. I. Alizadeh, M. Parsa Moghaddam, N. Amjady, P. Siano, and M. K. Sheikh-El-Eslami, "Flexibility in future power systems with high renewable penetration: A review," Renew. Sustain. Energy Rev., vol. 57, pp. 1186-1193, May 2016.

[201] G. Papaefthymiou and K. Dragoon, "Towards 100\% renewable energy systems: Uncapping power system flexibility,” Energy Policy, vol. 92, pp. 69-82, May 2016.

[202] P. D. Lund, J. Lindgren, J. Mikkola, and J. Salpakari, "Review of energy system flexibility measures to enable high levels of variable renewable electricity,” Renew. Sustain. Energy Rev., vol. 45, pp. 785-807, May 2015.

[203] North American Electric Reliability Corporation (NERC), "Flexibility requirements and metrics for variable generation,” 2010.

[204] J. Ma, V. Silva, R. Belhomme, D. S. Kirschen, and L. F. Ochoa, "Evaluating and planning flexibility in sustainable power systems," in 2013 IEEE Power Energy Society General Meeting, 2013, pp. 1-11.

[205] J. E. Bistline, "Economic and technical challenges of flexible operations under large-scale variable renewable deployment,” Energy Econ., vol. 64, pp. 363-372, May 2017.

[206] J. Ma, V. Silva, R. Belhomme, D. S. Kirschen, and L. F. Ochoa, "Exploring the use of flexibility indices in low carbon power systems," in 2012 3rd IEEE PES Innovative Smart Grid Technologies Europe (ISGT Europe), 2012, pp. 1-5.

[207] E. T. Hale, B. L. Stoll, and J. E. Novacheck, “Integrating solar into Florida's power system: Potential roles for flexibility,” Sol. Energy, vol. 170, pp. 741-751, Aug. 2018.

[208] M. Huber, D. Dimkova, and T. Hamacher, "Integration of wind and solar power in Europe: Assessment of flexibility requirements,” Energy, vol. 69, pp. 236-246, May 2014.

[209] International Renewable Energy Agency (IRENA), "Innovative ancillary services," Innovation landscape brief, 2019.

[210] International Renewable Energy Agency (IRENA), "Innovation landscape for a renewablepowered future: Solutions to integrate variable renewables (Preview for policy makers)," 2019.

[211] M. A. Gonzalez-Salazar, T. Kirsten, and L. Prchlik, "Review of the operational flexibility and emissions of gas- and coal-fired power plants in a future with growing renewables," Renew. Sustain. Energy Rev., vol. 82, pp. 1497-1513, Feb. 2018.

[212] J. Nelson et al., "Investigating the Economic Value of Flexible Solar Power Plant Operation," Energy and Environmental Economics, Inc., 2018.

[213] S. Dahlke and M. Morjaria, "Value of flexible solar - A simple model," First Solar, Sep. 2019.

[214] V. Gevorgian and B. O’Neill, “Advanced Grid-Friendly Controls Demonstration Project for Utility-Scale PV Power Plants,” NREL/TP--5D00-65368, 1236761, Jan. 2016.

[215] S. M. Alfaro, T. Á. Araya, G. O. Mercado, and N. Milan, "Demonstration of Ancillary Service Provision Capabilities of Photovoltaic Power Plants: Study Case Luz del Norte,” Laborelec, Apr. 2019.

[216] C. Loutan et al., "Demonstration of Essential Reliability Services by a 300-MW Solar Photovoltaic Power Plant,” NREL/TP--5D00-67799, 1349211, Mar. 2017.

[217] E. Ela et al., “Active Power Controls from Wind Power: Bridging the Gaps," NREL/TP--5D0060574, 1117060, Jan. 2014.

[218] X. Wang et al., "Evaluation of the inertial response of variable-speed wind turbines using advanced simulation,” in 2017 IEEE Power \& Energy Society General Meeting, Chicago, IL, 2017, pp. 1-5.

[219] E. Muljadi, V. Gevorgian, M. Singh, and S. Santoso, "Understanding inertial and frequency response of wind power plants," in 2012 IEEE Power Electronics and Machines in Wind Applications, Denver, CO, USA, 2012, pp. 1-8. 
[220] J. Morren, J. Pierik, and S. W. H. de Haan, “Inertial response of variable speed wind turbines," Electr. Power Syst. Res., vol. 76, no. 11, pp. 980-987, Jul. 2006.

[221] N. R. Ullah, K. Bhattacharya, and T. Thiringer, "Wind Farms as Reactive Power Ancillary Service Providers-Technical and Economic Issues,” IEEE Trans. Energy Convers., vol. 24, no. 3, pp. 661-672, Sep. 2009.

[222] V. Gevorgian, Y. Zhang, and E. Ela, "Investigating the Impacts of Wind Generation Participation in Interconnection Frequency Response,” IEEE Trans. Sustain. Energy, vol. 6, no. 3, pp. 10041012, Jul. 2015.

[223] J. Brisebois and N. Aubut, "Wind farm inertia emulation to fulfill Hydro-Québec's specific need," in 2011 IEEE Power and Energy Society General Meeting, 2011, pp. 1-7.

[224] Z. Miao, L. Fan, D. Osborn, and S. Yuvarajan, "Wind Farms With HVdc Delivery in Inertial Response and Primary Frequency Control,” IEEE Trans. Energy Convers., vol. 25, no. 4, pp. 1171-1178, Dec. 2010.

[225] A. Banshwar, N. K. Sharma, Y. R. Sood, and R. Shrivastava, "Renewable energy sources as a new participant in ancillary service markets,” Energy Strategy Rev., vol. 18, pp. 106-120, Dec. 2017.

[226] J. Sterling, C. Stearn, T. Davidovich, P. Quinlan, J. Pang, and C. Vlahoplus, "Proactive Solutions to Curtailment Risk: Identifying New Contract Structures for Utility-Scale Renewables,” Smart Electric Power Alliance.

[227] Hawaii Public Utilities Commission, “Applications for Approval of Power Purchase Agreement for Renewable Dispatchable Generation, Dockets 2018-0430 through 2018-0437.” .

[228] Hawaiian Electric, "Hawaii’s largest renewable energy push detailed in new procurement plan," 17-Jul-2019. .

[229] J. Després, S. Mima, A. Kitous, P. Criqui, N. Hadjsaid, and I. Noirot, “Storage as a flexibility option in power systems with high shares of variable renewable energy sources: a POLES-based analysis,” Energy Econ., vol. 64, pp. 638-650, May 2017.

[230] R. Loisel, "Power system flexibility with electricity storage technologies: A technical-economic assessment of a large-scale storage facility,” Int. J. Electr. Power Energy Syst., vol. 42, no. 1, pp. 542-552, Nov. 2012.

[231] A. A. Akhil et al., "DOE/EPRI Electricity Storage Handbook in Collaboration with NRECA," 2015.

[232] L. Goldie-Scot, “A Behind the Scenes Take on Lithium-ion Battery Prices,” BloombergNEF, 05Mar-2019.

[233] P. Denholm and M. Hand, "Grid flexibility and storage required to achieve very high penetration of variable renewable electricity,” Energy Policy, vol. 39, no. 3, pp. 1817-1830, Mar. 2011.

[234] United States Department of Energy (US DOE), “DOE Global Energy Storage Database,” 2019. [Online]. Available: https://www.energystorageexchange.org/projects. [Accessed: 29-Sep-2019].

[235] B. Paulos, “Converting renewable power to other low-carbon products,” Energy Transition, 10Jan-2018. .

[236] D. Gielen, M. D. Bazilian, K. B. Medlock III, and J. Logan, "Power-To-X In The German Experience: Another In The List Of Growing Energy Transition Strategies,” Forbes.

[237] A. Varone and M. Ferrari, "Power to liquid and power to gas: An option for the German Energiewende,” Renew. Sustain. Energy Rev., vol. 45, pp. 207-218, May 2015.

[238] T. Kober et al., "Perspectives of Power-to-X technologies in Switzerland," White Paper, 2019.

[239] G. Gahleitner, "Hydrogen from renewable electricity: An international review of power-to-gas pilot plants for stationary applications,” Int. J. Hydrog. Energy, vol. 38, no. 5, pp. 2039-2061, Feb. 2013.

[240] A. Ursua, L. M. Gandia, and P. Sanchis, "Hydrogen Production From Water Electrolysis: Current Status and Future Trends,” Proc. IEEE, vol. 100, no. 2, pp. 410-426, Feb. 2012.

[241] R. E. Clarke, S. Giddey, F. T. Ciacchi, S. P. S. Badwal, B. Paul, and J. Andrews, "Direct coupling of an electrolyser to a solar PV system for generating hydrogen,” Int. J. Hydrog. Energy, vol. 34, no. 6, pp. 2531-2542, Mar. 2009. 
[242] United States Energy Information Administration (US EIA), “Use of hydrogen - U.S. Energy Information Administration (EIA)."

[243] M. Götz et al., "Renewable Power-to-Gas: A technological and economic review," Renew. Energy, vol. 85, pp. 1371-1390, Jan. 2016.

[244] K. Hashimoto, N. Kumagai, K. Izumiya, H. Takano, and Z. Kato, "The production of renewable energy in the form of methane using electrolytic hydrogen generation,” Energy Sustain. Soc., vol. 4, no. 1, p. 17, Aug. 2014.

[245] J. Vandewalle, K. Bruninx, and W. D'haeseleer, "Effects of large-scale power to gas conversion on the power, gas and carbon sectors and their interactions,” Energy Convers. Manag., vol. 94, pp. 28-39, Apr. 2015.

[246] Z. He, M. Cui, Q. Qian, J. Zhang, H. Liu, and B. Han, "Synthesis of liquid fuel via direct hydrogenation of CO2,” Proc. Natl. Acad. Sci., vol. 116, no. 26, pp. 12654-12659, Jun. 2019.

[247] H. Blanco, W. Nijs, J. Ruf, and A. Faaij, "Potential for hydrogen and Power-to-Liquid in a lowcarbon EU energy system using cost optimization,” Appl. Energy, vol. 232, pp. 617-639, Dec. 2018.

[248] C. F. Shih, T. Zhang, J. Li, and C. Bai, “Powering the Future with Liquid Sunshine,” Joule, vol. 2, no. 10, pp. 1925-1949, Oct. 2018.

[249] H. L. Tuller, "Solar to fuels conversion technologies: a perspective," Mater. Renew. Sustain. Energy, vol. 6, no. 1, p. 3, Jan. 2017.

[250] M. Ferrari, "Fuel from Green Power and CO2: The New Power-to-Liquid Plant in Dresden,” Institute for Advanced Sustainability Studies, 24-Nov-2014.

[251] W. LIU, F. WEN, and Y. XUE, "Power-to-gas technology in energy systems: current status and prospects of potential operation strategies,” J. Mod. Power Syst. Clean Energy, vol. 5, no. 3, pp. 439-450, May 2017.

[252] M. Jentsch, T. Trost, and M. Sterner, "Optimal Use of Power-to-Gas Energy Storage Systems in an 85\% Renewable Energy Scenario,” Energy Procedia, vol. 46, pp. 254-261, Jan. 2014.

[253] M. H. Albadi and E. F. El-Saadany, “A summary of demand response in electricity markets," Electr. Power Syst. Res., vol. 78, no. 11, pp. 1989-1996, Nov. 2008.

[254] A. Faruqui and S. S. George, “The Value of Dynamic Pricing in Mass Markets,” Electr. J., vol. 15, no. 6, pp. 45-55, Jul. 2002.

[255] S. Borenstein and S. Holland, "On the efficiency of competitive electricity markets with timeinvariant retail prices,” RAND J. Econ., vol. 36, no. 3, pp. 469-493, 2005.

[256] S. Dahlke and M. Prorok, "Consumer Savings, Price, and Emissions Impacts of Increasing Demand Response in the Midcontinent Electricity Market,” Energy J., vol. 40, no. 3, Jul. 2019.

[257] S. Bouckaert, V. Mazauric, and N. Maïzi, "Expanding Renewable Energy by Implementing Demand Response,” Energy Procedia, vol. 61, pp. 1844-1847, Jan. 2014.

[258] B. Feldman, "Demand Response for Renewables Integration: Making a Smart Grid for Tomorrow,” Renewable Energy World, 04-Dec-2017.

[259] N. Hajibandeh, M. Ehsan, S. Soleymani, M. Shafie-khah, and J. P. S. Catalão, "The Mutual Impact of Demand Response Programs and Renewable Energies: A Survey,” 2017.

[260] S. Kiliccote, P. Sporborg, I. Sheikh, E. Huffaker, and M. A. Piette, "Integrating renewable resources in California and the role of automated demand response,” Lawrence Berkeley National Lab (LBNL), 2010. 